\title{
Analysis of several bioclimatic indices for viticultural zoning in the Pacific Northwest
}

\author{
Golnaz Badr ${ }^{1,4, *}$, Gerrit Hoogenboom ${ }^{1,5}$, Mohammad Abouali ${ }^{2}$, Michelle Moyer ${ }^{3}$, \\ Markus Keller ${ }^{3}$ \\ ${ }^{1}$ AgWeatherNet Program, Washington State University, Prosser, Washington 99350, USA \\ ${ }^{2}$ Data Scientist at Ford Motor Company, Dearborn, Michigan 48120, USA \\ ${ }^{3}$ Viticulture and Enology, Department of Horticulture, Washington State University, Prosser, Washington 99350, USA \\ ${ }^{4}$ Present address: Cornell Lake Erie Research and Extension Lab, Portland, NY 14769, USA \\ ${ }^{5}$ Present address: Institute for Sustainable Food Systems, University of Florida, Gainesville, Florida 32611-0570, USA
}

\begin{abstract}
The growth and development of grapevines Vitis vinifera L. are highly dependent on the weather dynamics of a region. The goal of this study was to use long-term historical weather data to obtain and develop several bioclimatic indices that are of viticultural importance. In this study, several bioclimatic indices were computed using $30 \mathrm{yr}$ (1983-2012) of daily weather data that were obtained from the gridded surface meteorological dataset at the University of Idaho (UI GSM). The bioclimatic indices were determined for each of the American viticultural areas (AVA) located in the State of Washington and parts of northeast Oregon. Several new indices including dynamic minimum temperature (DyMin.Temp.), cold damage index (CDI), and wind speed index (WSI) were developed based on previous indices and models. Considering all AVAs, the mean frost free days (FFD) ranged from 146 to 230; the mean growing degree days (GDD) ranged from 948 to 1662; the mean biologically effective degree days (BEDD) ranged from 318 to 1590; the mean Huglin Index (HI) ranged from 1452 to 2425; the mean length of growing season (LGS) ranged from 164 to 189 days; and the mean growing season suitability (GSS) ranged from $82 \%$ to $92 \%$. Once these data were obtained, the bioclimatic indices were then used to categorize the AVAs. These relative categories provide knowledge of climate potential in the study area for optimal grape production, potentially enabling us to match the best cultivars to a site based on its specific climate dynamics.
\end{abstract}

KEY WORDS: American viticultural areas - AVAs - Cold damage index - Wind speed index · Dynamic minimum temperature index $\cdot$ GIS

\section{INTRODUCTION}

Weather plays a primary role in grapevine (Vitis spp.) growth and development (Van Leeuwen et al. 2004, Fraga et al. 2013), and specific environmental conditions determine grapevine physiology and development (Jackson 2008, Magalhães 2008, Santos et al. 2012, Tóth \& Végvári 2016). A strong correlation has been reported between grape yield and climate traits for a specific region, such as monthly mean tem-

\footnotetext{
${ }^{*}$ Corresponding author: gb482@cornell.edu
}

perature and total precipitation during the growing season for a specific region (Makra et al. 2009, Santos et al. 2013). Jones et al. (2004) described climate as the most profound factor in determining the ability of a region to produce quality grapes. The macroclimate requirements for vines stipulate that the lowest temperature during the winter does not drop below -15 to $-20^{\circ} \mathrm{C}$ and that there is a minimum of 1000 growing degree days with a base temperature of $10^{\circ} \mathrm{C}$ (Van Leeuwen \& Seguin 2006). The meso-

() The authors 2018. Open Access under Creative Commons by Attribution Licence. Use, distribution and reproduction are unrestricted. Authors and original publication must be credited. 
climate is mainly determined by the topography of a region (Keller 2010), while the micro-climate is primarily decided by local soil and canopy management and is focused on the fruit zone (White 2015).

\subsection{Bioclimatic indices}

Several indices have been developed based on the heat load (daily accumulated temperatures above a threshold of $10^{\circ} \mathrm{C}$ for a fixed period) and temperature requirements of grapevines. The bioclimatic indices were placed into 5 major categories: (1) bioclimatic indices focusing on heat unit accumulation; (2) bioclimatic indices focusing on length of growing season; (3) bioclimatic indices focusing on minimum temperature; (4) bioclimatic indices focusing on precipitation; and (5) bioclimatic indices focusing on wind speed.

\subsubsection{Bioclimatic indices focusing on heat unit accumulation}

The Winkler index (WI) (Winkler et al. 1974, Jones et al. 2010), more commonly recognized as growing degree days (GDD), refers to the degree day units accumulated during the growing season with a base temperature of $10^{\circ} \mathrm{C}$. This required heat load (GDD) is a function of grapevine variety; therefore, the reported minimum value and optimal range of the GDD can vary. In our study, GDD was computed based on a fixed growing season from April to October in order to facilitate comparisons with other grape-producing regions. The Huglin index (HI) (Huglin 1978) combines the air temperature during the active period of vegetative growth with a coefficient of day length that varies according to the latitude (see Table S1 in the Supplement at www.int-res.com/articles/suppl/c076 p203_supp.pdf). It provides valuable information on the local heat summations by considering the average and maximum temperatures and weighting the accumulated temperatures to the daytime period. Huglin \& Schneider (1998) classified grape varieties based on HI. Growing season temperature (GST) (Jones 2005) is the average temperature of the growing season from April to October. Biologically effective degree days (BEDD or $\mathrm{E}^{\circ}$ ) (Gladstones 1992) account for heat accumulations that are defined by upper and lower temperature thresholds (between 10 and $19^{\circ} \mathrm{C}$ ), and the BEDD formulation also modifies the heat accumulation for diurnal ranges (Table S1). Gladstones (1992) applied BEDD to define corresponding maturity groupings of various grape cultivars (Table 1).
The HI and BEDD use a coefficient ( $k$ ) to represent the changes in day length imposed by latitude (Table S1). The increase in day length during the growing season increases potentially relative to an increase in latitude. A clear definition of $k$ does not exist; however, Huglin (1978) categorized $k$ based on the latitudes between $40^{\circ}$ and $50^{\circ}$ into 5 classes, where $k$ had a range of 1.02 to 1.06 . The $k$ for latitudes equal to or lower than $40^{\circ}$ was reported to be 1 (Huglin 1978, Tonietto \& Carbonneau 2004). The latitude temperature index (LTI) (Jackson \& Cherry 1988 ) is the result of multiplying the mean temperature of the warmest month by the subtraction of latitude $(\varphi)$ of the location from $60(60-\varphi)$.

\subsubsection{Bioclimatic indices focusing on length of} growing season

Growing season suitability (GSS) (Malheiro et al. 2010, Santos et al. 2012) is the fraction of days from April to September with a daily mean air temperature above $10^{\circ} \mathrm{C}$. The time frames are based on the standard formulation of the indices to be able to facilitate the comparison among various regions. The length of growing season (LGS) (Jackson 2008) is the number of days with mean temperatures above $10^{\circ} \mathrm{C}$ for a growing season ranging from April 1 to October 31. The frost free days index (FFD) (Magarey et al. 1998) is used to determine growing season length; it is the period between the last frost (temperatures below $0^{\circ} \mathrm{C}$ ) in spring and the first frost in fall.

\subsubsection{Bioclimatic indices focusing on minimum temperature}

The cool night index (CI) (Tonietto \& Carbonneau 2004) takes into account the minimum temperature during grape maturation, which is normally the average minimum air temperature in September. Mean thermal amplitude (MTA) (Mullins et al. 1992, Ramos et al. 2008) is the difference between the minimum and maximum temperature in September and is associated with grape quality and composition (Montes et al. 2012). Adjustments to MTA should be made based upon phenology and not calendar. Temperatures below $-17^{\circ} \mathrm{C}$ are commonly considered the lethal lower temperature limit for grapes; defined as the minimum temperature index (Min.Temp.) (Hidalgo 2002), a vital constraint of growing grapevines. However, cold acclimation is a physiological process that happens over a period of time, so using a single 
Table 1. Wine grape maturity groupings and corresponding biologically effective degree days (BEDD) to ripeness (Gladstones 1992)

\begin{tabular}{|c|c|c|}
\hline & Red & White or Rosé \\
\hline \multicolumn{3}{|l|}{ Group 1} \\
\hline 1050 day $^{\circ}$ & - & Madeline, Madeline-Sylvaner \\
\hline \multicolumn{3}{|l|}{ Group 2} \\
\hline 1100 day $^{\circ}$ & Blue Portuguese & $\begin{array}{c}\text { Chasselas, Muller-Thurgau, Siegerrebe, Bacchus, } \\
\text { Pinot Gris, Muscat Ottonel, Red Veltliner, Pinot Noir, } \\
\text { Meunier }\end{array}$ \\
\hline \multicolumn{3}{|l|}{ Group 3} \\
\hline 1150 day $^{\circ}$ & $\begin{array}{c}\text { Pinot Noir, Meunier, Gamay, Dolcetto, Bastardo, } \\
\text { Tinta Carvalha, Tinta Amarella }\end{array}$ & $\begin{array}{c}\text { Traminer, Sylvaner, Scheurebe, Elbling, Morio-Muskat, } \\
\text { Kerner, Green Veltliner, Chardonnay, Aligote, Melon, } \\
\text { Sauvignon, Blanc, Frontignac, Pedro Ximénez, } \\
\text { Verdelho, Sultana }\end{array}$ \\
\hline \multicolumn{3}{|l|}{ Group 4} \\
\hline 1200 day $^{\circ}$ & $\begin{array}{l}\text { Malbec, Durif, Zinfandel, Schiava (=Trollinger), } \\
\text { Tempranillo, Tinta Maderia, Pinotage }\end{array}$ & $\begin{array}{c}\text { Semillon, Muscadelle, Riesling, Welschriesling, } \\
\text { Furmint, Leanyka, Harslevelu, Sercial, Malvasia } \\
\text { Bianica, Carbernet Franc }\end{array}$ \\
\hline \multicolumn{3}{|l|}{ Group 5} \\
\hline 1250 day $^{\circ}$ & $\begin{array}{c}\text { Merlot, Carbernet Franc, Shiraz, Cinsaut, } \\
\text { Barbera, Sangiovese, Touriga }\end{array}$ & $\begin{array}{l}\text { Chenin Blanc, Folle Blanche, Crouchen, Rousanne, } \\
\text { Masanne, Viognier, Taminga, Carbernet Sauvignon }\end{array}$ \\
\hline \multicolumn{3}{|l|}{ Group 6} \\
\hline 1300 day $^{\circ}$ & $\begin{array}{c}\text { Cabernet Sauvignon, Ruby Cabernet, } \\
\text { Mondeuse, Tannat, Kadarka, Corvina, Nebbi- } \\
\text { olo, Ramisco, Alvarelhao, Mourisco Tinto, } \\
\text { Valdiguie }\end{array}$ & $\begin{array}{c}\text { Colombard, Palomino, Dona Branca, Rabigato, } \\
\text { Grenache }\end{array}$ \\
\hline \multicolumn{3}{|c|}{ 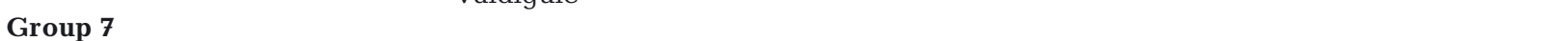 } \\
\hline 1350 day $^{\circ}$ & $\begin{array}{l}\text { Aramon, Petit Verdot, Mataro, Carignan, } \\
\text { Grenache, Freisa, Negrara, Grignolino, Souzao, } \\
\text { Graciano, Monastrell }\end{array}$ & Muscat Gordo Blanco, Trebiano, Montils \\
\hline \multicolumn{3}{|l|}{ Group 8} \\
\hline 1400 day $^{\circ}$ & Tarrango, Terret Noir & Clairette, Grenache Blanc, Doradillo, Biancone \\
\hline
\end{tabular}

temperature threshold may not be effective in capturing grapevine behavior in response to low temperature. In reality, lethal low temperatures are dynamic and vary based on the cold hardiness status of each grapevine cultivator. Grapevine cold hardiness is a dynamic phenomenon that responds to seasonal changes in air temperature (Ferguson et al. 2011). Cold hardiness starts with the acclimation at the end of the growing season (fall), which coincides with a decrease in the air temperature. During the winter, when temperatures are low and stable, cold hardiness remains steady. De-acclimation begins when the temperature rises at the end of winter/early spring (Ferguson et al. 2011). The injuries caused by frost and freezes on grapes are well documented (Wample et al. 2001, Fennell 2004, Davenport et al. 2008); however, there are differences among cultivars in terms of their cold hardiness (Clark et al. 1996, Wolfe 2001, Fennell 2004, Mills et al. 2006, Davenport 2008, Ferguson et al. 2011, 2014). In regions where plants complete their development be- fore the start of frost, crop load and plant nutrient status have no significant effect on the cold hardiness of grapes. (Davenport 2008). The temperature at which $50 \%$ of the organ or sample tissue is injured due to a freeze is called $\mathrm{LT}_{50}$ (Ferguson et al. 2011), and the prediction of cold hardiness is primarily based on the measured $\mathrm{LT}_{50}$ of the dormant buds of multiple grape cultivars (Ferguson et al. 2011).

\subsubsection{Bioclimatic indices focusing on precipitation}

The growing season precipitation index (GSP) (Blanco-Ward et al. 2007) provides the general suitability used in climate zoning for viticulture that accumulates precipitation during the growing season (Table S1). However, the GSP is only relevant for regions where grapes are normally not irrigated. The hydrothermic index (HyI) (Branas 1974) combines the effect of air humidity and temperature using precipitation as a surrogate during the growing season 
to assess the risk of grapevine exposure to certain diseases, such as downy mildew, as well as water stress.

\subsubsection{Bioclimatic index focusing on wind speed}

The impact of high wind speeds on grapevine growth and yield is well documented (Takahashi et al. 1976, Freeman et al. 1982, Hamilton 1988, Jackson 2008, Keller 2010), but no comprehensive index has been developed using wind speed as a supplemental tool for viticultural zoning. Previous studies have indicated that strong winds can cause physical damage to grapevines (Hamilton 1988) as wind speed impacts evapotranspiration due to its impact on stomatal resistance (Dry et al. 1989, CampbellClause 1998, Tarara et al. 2005, Keller 2010) and boundary layer thickness (Keller 2010). Jackson (2008) discussed the impact of wind velocity on the heating of grape berries, canopy water deficiency, irrigation systems, soil erosion, disease dispersion, physical damage to vines, shoot length, leaf size, stomatal density, number of clusters per vine, ripening, and the solid solubility. The impact of wind is increased by the number of wind perturbations (Williams et al. 1994, Tarara et al. 2005, Keller 2010). Gladstones (1992) reported 2 types of damage resulting from strong winds: (1) injury caused by strong winds in spring and early summer that mainly affects young and tender growth; and (2) injury caused by hot, dry winds in summer that damages the vines, and leads to imperfect ripening and the collapse of berries.

\subsection{Bioclimatic zoning of grape-growing regions}

\subsubsection{Climatic zones outside the USA}

Several studies have used bioclimatic indices to classify potential grapevine-growing regions across the globe. Jackson \& Cherry (1988) calculated and compared 14 bioclimatic indices for 78 locations in Europe, Australia, and New Zealand to determine the most useful index among those proposed for the classification of grape-growing regions. They reported LTI and HI to be the best indices for differentiation of grape-growing regions, based on the information provided on the heat requirements of different cultivars. The climate dataset was obtained via weather stations, and, therefore, the temporal and spatial resolutions were not optimal. Tonietto \&
Carbonneau (2004) undertook a climatic classification that combined HI, CI, and dryness index (DI), and found that $\mathrm{HI}$ and CI were able to describe most of the variability within the climatic zones of grapeproducing regions around the world. However, they used World Meteorological Organization (WMO) stations that were located near each grape-producing region. This weather dataset was based on the point measurements provided by the weather stations and, therefore, did not spatially cover the study area. Jones et al. (2009) also determined the climatic indices for grape-growing regions worldwide using several bioclimatic indices, including $\mathrm{HI}, \mathrm{CI}, \mathrm{DI}$, BEDD, and GST. They utilized WorldClim (WorldClim 2009) $1 \mathrm{~km}$ resolution for the period from 1950 to 2000 with a temporal resolution of monthly data. Jones et al. (2009) recommended use of climate grids with a finer spatial resolution and recent weather data to update bioclimatic indices. With an improved climate structure, the variability and change of suitability can be monitored more accurately and efficiently (Jones et al. 2009). Santos et al. (2012) provided a macro-climate and classification analysis for grape-growing regions in Europe. They used the ENSEMBLES observational gridded data set for Europe (E-OBS) from the EU-FP6 project ENSEMBLES (http://ensembles-eu.metoffice.com) for a period of $59 \mathrm{yr}$ (1950 to 2009) for the European continent and calculated the GSS, GSP, Min.Temp., CI, WI, HI, DI, HyI, and composite index (CompI) in order to determine any potential trends in the individual indices. They identified significant trends in WI and HI, and using a canonical correlation analysis, demonstrated that the observed inter-annual variability of the $\mathrm{HI}$ was strongly controlled by large-scale atmospheric circulations during the growing season. Santos et al. (2012) also analyzed the inter-annual variability and long-term trends in the bioclimatic indices and updated the indices using high-resolution datasets for Europe.

Hall \& Jones (2010) calculated GST, GDD, HI, and BEDD for Australian wine grape growing regions from 1971 to 2000 and found that knowledge of climate dynamics helps to better understand the cultivar suitability within each region. Anderson et al. (2012) used daily historical data from weather stations (1971 to 2000) to calculate bioclimatic indices such as GST, WI, HI, and BEDD, and then interpolated the indices to a spatial grid with a $500 \mathrm{~m}$ resolution. They found that elevation plays an important role in determining the climate suitability of a particular region for grape production. They argued that GST and WI functionally capture the same informa- 
tion, and that $\mathrm{HI}$ is most capable of representing the actual structure of suitable regions for grape production in New Zealand. However, they suggested the need for within-region assessment of potentially suitable areas in future studies. Montes et al. (2012) used CI, DI, HI, and MTA for a multi-criteria climate classification of 7 Chilean viticultural valleys represented by 54 different weather stations. They reported that CI did not accurately represent climate variation in Chile and lacked discriminating capacity. Montes et al. (2012) found a similar spatial trend for MTA and $\mathrm{HI}$, and concluded that MTA was a suitable index for characterizing the thermal regime in Chile. Conceição \& Tonietto (2005) evaluated the climate potential of 3 regions in Brazil by calculating HI, CI, and DI using average historical meteorological data obtained from weather stations in those areas.

\subsubsection{Climatic zones in the USA}

The most suitable climatic zones for viticulture in California were first classified by Amerine \& Winkler (1944) and Winkler et al. (1974). They were later updated for the western USA by Jones et al. (2010) using PRISM (parameter-elevation relationships on independent slopes model) (Daly et al. 2008) for the period from 1971 to 2000 with a spatial resolution of 15 arc-seconds $(400 \mathrm{~m})$ and a monthly temporal resolution. Jones et al. (2010) calculated 4 bioclimatic indices, including GDD, HI, BEDD, and GST, and emphasized the importance of updating the longterm weather data for the calculation of bioclimatic indices. Yau (2011) computed GDD, LTI, and FFD using the PRISM monthly dataset for the Pacific Northwest (PNW) region of the USA. Yau et al. (2013) used principal component analysis (PCA) to determine the dominant factors influencing the AVAs in the PNW region, and found that the combination of elevation, GDD, FFD, and precipitation was the most important. They concluded that the climate component of AVAs is the most difficult to obtain and analyze, implying that any research capable of providing an improved climate component would enable the advancement of characterization of AVAs in the PNW region. Badr et al. (2018) used several bioclimatic indices coupled with soil and topography information to delineate the suitable areas for growing wine grapes in the State of Washington.

The objectives of our study were to conduct statistical analysis of several bioclimatic indices for the AVAs located in the State of Washington and parts of northeastern Oregon, and to develop new indices based on the cold hardiness dynamics of grapes, minimum temperature, and wind speed thresholds.

\section{MATERIALS AND METHODS}

\subsection{American Viticultural Areas (AVAs)}

Officially recognized appellations that allow vintners and consumers to attribute wine characteristics to the specific geographic origin of its grapes are called AVAs (TTB 2015). AVAs are acknowledged by the TTB, and the US Department of the Treasury allows vintners to describe the origin of their wine to consumers (TTB 2015). In the PNW region of the

Table 2. Area, elevation and year of recognition and other properties of American viticultural areas (AVAs) in the study area

\begin{tabular}{|c|c|c|c|c|c|c|}
\hline \multirow[t]{2}{*}{ AVA } & \multirow[t]{2}{*}{ State(s) } & \multirow{2}{*}{$\begin{array}{c}\text { Area } \\
\text { (ha) }\end{array}$} & \multicolumn{3}{|c|}{ Elevation $(\mathrm{m})$} & \multirow{2}{*}{$\begin{array}{c}\text { AVA } \\
\text { recognition } \\
\text { year }\end{array}$} \\
\hline & & & Min. & Max. & Mean & \\
\hline Columbia Valley & Washington-Oregon & 4597090 & 20 & 1442 & 451 & 1984 \\
\hline Puget Sound & Washington & 1179606 & 0 & 1046 & 109 & 1995 \\
\hline Yakima Valley & Washington & 289775 & 128 & 1099 & 339 & 1983 \\
\hline Horse Heaven Hills & Washington & 233160 & 81 & 671 & 321 & 2005 \\
\hline Walla Walla & Washington-Oregon & 129059 & 122 & 696 & 315 & 1984 \\
\hline Ancient Lakes of the Columbia Valley & Washington & 68607 & 173 & 583 & 377 & 2012 \\
\hline Columbia Gorge & Washington-Oregon & 48431 & 23 & 840 & 377 & 2004 \\
\hline Wahluke Slope & Washington & 32631 & 122 & 504 & 251 & 2005 \\
\hline Rattlesnake Hills & Washington & 29934 & 258 & 922 & 434 & 2006 \\
\hline Lake Chelan & Washington & 13291 & 278 & 1152 & 445 & 2009 \\
\hline Naches Heights & Washington & 5315 & 359 & 647 & 543 & 2012 \\
\hline Red Mountain & Washington & 1837 & 167 & 429 & 228 & 2001 \\
\hline Snipes Mountain & Washington & 1585 & 224 & 399 & 280 & 2009 \\
\hline The Rocks District of Milton-Freewater & Oregon & 1483 & 241 & 307 & 278 & 2015 \\
\hline
\end{tabular}




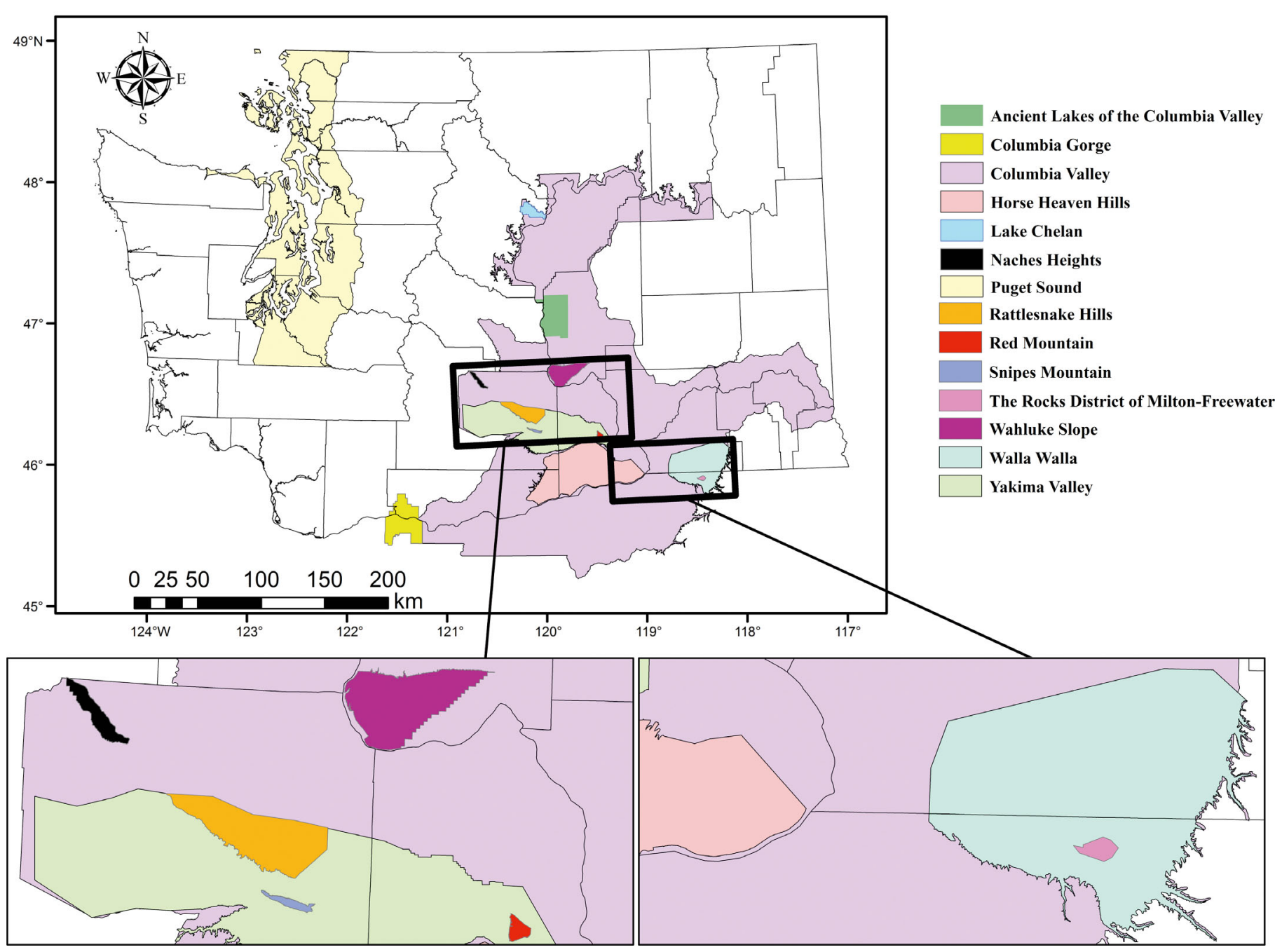

Fig. 1. Geographic locations of the Washington-Oregon American viticultural areas (AVAs)

USA, a total of 14 AVAs have been established in the State of Washington and eastern and north-central Oregon (Table 2, Fig. 1). The Columbia Valley is the largest, covering an area of 4597090 ha, while the Yakima Valley was the first AVA to be federally recognized in Washington in 1983 (Washington State Wines [WSW] 2015). The most recent AVA to be federally recognized was Oregon's Rocks District of Milton-Freewater in 2015, which is enclosed by the Walla Walla AVA.

Several of the AVAs in the PNW are shared among Washington and eastern and north-central Oregon (Fig. 1). The study area was, therefore, expanded to include parts of Oregon in order to calculate the bioclimatic indices for all the shared AVAs. The latitude ranged from $45.25^{\circ}$ to $49^{\circ} \mathrm{N}$ and the longitude ranged from $116.8^{\circ}$ to $124.78^{\circ} \mathrm{W}$. The total area under grape cultivation in Washington was 27186 ha, based on the USDA published statistics for 2012, and it is expanding annually (USDA-NASS 2015).

\subsection{Weather data}

We used weather data obtained from the University of Idaho's gridded surface meteorological data (UI GSM 2015). The UI GSM (Abatzoglou 2011) employs the spatial attributes of PRISM (Daly et al. 2008), with temporal attributes of regional-scale reanalysis and daily gauge-based precipitation from the North American land data assimilation system phase 2 (NLDAS-2; Mitchell et al. 2004). The dataset has a spatial resolution of $4 \mathrm{~km}$ for the contiguous United States and a daily temporal resolution. The UI GSM was evaluated by Abatzoglou (2013) through comparing the dataset with the observed data recorded 
by weather station networks such as RAWS (RAWS 2011), AgriMet (AgriMet 2011), AgWeatherNet (AgWeatherNet 2011), and USHCN-2 (USHCN 2011).

The daily minimum and maximum air temperatures of the dataset have a reported median error of 1.7 to $2.3^{\circ} \mathrm{C}$, and the median correlations of the daily maximum and minimum air temperatures are reported to be 0.94 to 0.95 and 0.87 to 0.90 , respectively (Abatzoglou 2013). For the wind speed, median correlations of 0.54 and 0.68 were reported during the cold season (October to April) and correlations of 0.52 and 0.62 for the warm season (May to September), revealing an overestimation ranging from 5\% to $30 \%$ (Abatzoglou 2013). Still, the dataset has great potential for landscape-scale modeling in areas where there is a limited amount of comprehensive, long-term, daily historical weather data (Abatzoglou 2013).

In our study, the bioclimatic indices were calculated using several variables obtained from the UI GSM, which covered a period of $30 \mathrm{yr}$ (1983 to 2012). The variables included precipitation, temperature, and wind velocity at $10 \mathrm{~m}$ above ground. The initial resolution was $4 \mathrm{~km}$, and was downscaled to a spatial resolution of $482 \mathrm{~m}$ using a bi-linear interpolation algorithm (MATLAB V2014a 2014); the indices were developed for the period between 1983 and 2012. For our study, the day length/latitude coefficient $(k)$ required for obtaining $\mathrm{HI}$ and BEDD was calculated by applying a linear interpolation to the previously reported $k$ for each region. This interpolation modified $k$ based on linear changes in latitude. The $k$ was linearly increased from 1.03 to 1.06 by increasing the latitude from $44^{\circ}$ to $50^{\circ}$.

The bioclimatic indices for each AVA were extracted using ArcGIS v.10 (ESRI 2015) based on the AVA boundaries. All the shapefiles, except for the Rocks District of Milton-Freewater, were obtained courtesy of the Davenport Laboratory, Washington State University Irrigated Agriculture and Research and Extension Center, Prosser, WA, USA. The computed bioclimatic indices were statistically compared among AVAs to detect significant differences at the $95 \%$ confidence level. The statistical analysis was conducted to compare the mean values using the ANOVA test with SAS v.9.4. at a 95\% level (SAS 2015). It should be noted that the AVAs differed in area and number of pixels, and were also not independent, as Columbia Valley encompasses most of the AVAs located in eastern Washington (Fig. 1). However, use of statistical techniques can assist with further categorizing these AVAs to obtain more profound insight into how each AVA compares with the others.

\subsection{CDI}

Acclimation of grapevines to cold weather in fall for regions located in the northern hemisphere is called cold hardiness and it varies greatly based on variety and region. The cold hardiness $\left(H_{C, i}\right)$ for day $i$ is computed based on the cold hardiness of the previous day $\left(H_{C, i-1}\right)$ plus the changes in the cold hardiness $\left(\Delta H_{C}\right)$ over the course of a single day (Eq. 1). The cold hardiness was computed for a hypothetical cultivar to ensure that the most sensitive cultivars were taken in to account.

$$
H_{C, i}=H_{C, i-1}+\Delta H_{C}
$$

The changes in cold hardiness $\left(\Delta H_{C}\right)$ were computed as follows:

$$
\Delta H_{C}=\left(D D_{C}+k_{a} \times C_{\log _{1} \mathrm{a}}\right)+\left(D D_{h}+k_{d} \times C_{\log , \mathrm{d}}\right)
$$

where $k_{\mathrm{a}}$ is the constant for acclimation rate, $k_{\mathrm{d}}$ is the constant for de-acclimation rate, $C_{\log _{1} \text { a }}$ is the dimensionless logistic component for acclimation, $C_{\text {log,d }}$ is the de-acclimation logistic component, $D D_{c}$ represents the chilling degree days, and $D D_{h}$ the heating degree days (Ferguson et al. 2011, 2014). The initial cold hardiness $\left(H_{C \text {,initial }}\right)$ was modified to $-3^{\circ} \mathrm{C}$, which is the reported hardiness of green tissue (Fennell 2004).

The CDI was developed to evaluate the minimum daily temperature in a specific location with respect to the predicted $\mathrm{LT}_{50}$ for that location. The index utilizes a predicted $\mathrm{LT}_{50}$ to count the number of events that occur when the daily minimum temperature falls below the $\mathrm{LT}_{50}$ threshold. Hence, the CDI compares the minimum daily temperature with the predicted $\mathrm{LT}_{50}$ for a given day. If the minimum temperature falls below the threshold, it is counted as 1 event. Consequently, the number of events can be counted for each month, and the total number of incidents per year can then be summed up to calculate the annual CDI. Depending on the availability of long-term weather data, CDI can be computed for several years. It is also possible to sum up the CDI for periods of $5,10,20$, and $30 \mathrm{yr}$, and then discuss the probability of the occurrence of critical low temperatures in a region based on the results. In fact, CDI could be computed for $30 \mathrm{yr}$ and then used to calculate the CDI for $100 \mathrm{yr}$.

\subsection{DyMin.Temp.}

The DyMin.Temp. was created as a modification of the Min.Temp. (Table S1). By comparing the daily minimum temperatures with the dynamic low thresh- 
old for each month, grapevines' various levels of sensitivity to low temperatures during both the growing season and winter can be monitored for each location. The DyMin.Temp. compares daily low air temperatures with the assigned threshold for a particular month $\left(T_{t}\right)$; consequently, it calculates the number of events (d) when the temperature fell below a certain threshold during a particular month. The total number of incidents occurring in a single month ranges from 0 ('no events') to the number of days in a particular month, ultimately leading to the determination of the total number of incidents occurring within a specific month. Depending on the availability of a given region's long-term weather data, the total number of events recorded for each month must then be averaged for each year of the study. The DyMin.Temp. was ultimately obtained by summing up the average number of events that occurred within each individual month for a specific 12 mo period (Eq. 3).

$$
T_{\text {Dynamic min }}=\sum_{m=\mathrm{Jan}}^{\text {Dec }} \bar{e}_{m}
$$

where $T_{\text {Dynamic min }}$ is the dynamic minimum temperature and $\bar{e}_{m}$ is the average number of events in month $m$ (Eq. 4).

$$
\bar{e}_{m}=\frac{1}{n} \sum_{1983}^{2012} e_{T, y, m}
$$

where $n$ is the number of years and $e_{T, y, m}$ is the number of events occurring within a specified year and month, as denoted by $y$ and $m$, respectively (Eq. 5).

$$
e_{T, y, m}=\sum_{d=1}^{\mathrm{eom}(y, m)} \operatorname{cond}_{T}\left(T_{\min , y, m, d}, T_{t h, m}\right)
$$

where eom $(y, m)$ (end of month) returns the number of days in a given month and year, represented by $m$ and $y, T_{\min , y, m, d}$ is the minimum temperature for a specific day, $T_{t h, m}$ is the temperature threshold for a chosen month (the thresholds were as follows: January and December $=-10^{\circ} \mathrm{C}$; October, November, and February $=-5^{\circ} \mathrm{C}$, March $=-3^{\circ} \mathrm{C}$, and April to September $\left.=0^{\circ} \mathrm{C}\right)$, and $\operatorname{cond}_{T}\left(T_{\min , y, m, d r} T_{t h, m}\right)$ is defined as follows (Eq. 6):

$$
\operatorname{cond}_{T}\left(T_{\min , y, m, d}, T_{t h, m}\right)=\left\{\begin{array}{cc}
1 & T_{\min , y, m, d}<T_{t h, m} \\
0 & \text { otherwise }
\end{array}\right.
$$

\subsection{Wind speed index (WSI)}

The WSI was developed to help address the impact of wind speed on viticultural zoning. The WSI initially takes into account the $10 \mathrm{~m}$ daily average wind velocity $\left(\bar{U}_{y, m, d}\right)$. WSI essentially uses the same procedure as described for DyMin.Temp., but uses $e_{W, y, m}$ instead of $e_{T, y, m}$ (Eq. 7).

$$
e_{W, y, m}=\sum_{d=1}^{\mathrm{eom}(y, m)} \operatorname{cond}_{W}\left(\bar{U}_{y, m, d}, U_{t h}\right)
$$

where $\bar{U}_{y, m, d}$ is the average wind velocity for the specified day, $U_{t h}$ is the wind velocity threshold, and the $\operatorname{cond}_{w}\left(\bar{U}_{Y, m, d} U_{t h}\right)$ is obtained as follows (Eq. 8):

$$
\operatorname{cond}_{W}\left(\bar{U}_{y, m, d}, U_{t h, m}\right)=\left\{\begin{array}{cc}
1 & \bar{U}_{y, m, d}>U_{t h} \\
0 & \text { otherwise }
\end{array}\right.
$$

The $\bar{U}_{\text {th }}$ used in our study was $4 \mathrm{~m} \mathrm{~s}^{-1}$ (Freeman et al. 1982, Hamilton 1988, Hunter \& Bonnardot 2011). Since the daily wind velocities obtained from the UI GSM were based on $10 \mathrm{~m}$ wind speeds, the logarithmic wind profile conversion equation was used to convert the threshold to a $2 \mathrm{~m}$ wind velocity (Allen et al. 1998).

\subsection{Precipitation}

Spatio-temporal analysis of the precipitation used in our study was divided into 2 groups: (1) precipitation during the growing season (GSP) (BlancoWard et al. 2007); and (2) out-of-growing-season precipitation (OutGSP). The motivation for dividing precipitation into 2 distinct groups was to obtain a better understanding of local water availability prior to the start of a new growing season. This knowledge can help decision-makers, extension specialists, and growers gain more insight into the need for irrigation of grapes in specific regions. For each AVA, the total precipitation was calculated and the percentage of precipitation was also obtained. OutGSP is a particularly useful index as it can potentially indicate the amount of water available for filling the soil profile prior to the start of a new growing season.

\section{RESULTS AND DISCUSSION}

\subsection{Bioclimatic indices focusing on thermal heat unit accumulation}

\subsubsection{BEDD}

BEDD were computed for each AVA. Puget Sound had the lowest $\mathrm{BEDD}\left(318^{\circ} \mathrm{C} \mathrm{BEDD}\right)$, while the highest was obtained for Snipes Mountain $\left(1590^{\circ} \mathrm{C}\right.$ BEDD) (Table 3, Table S2 in the Supplement). Jones 
Table 3. The average biologically effective degree days (BEDD) calculated for each American viticultural areas (AVAs) in the study area. The classification only pertains to this index (based on Jones et al. 2010). (-) Not applicable

\begin{tabular}{|lccc|}
\hline AVA & $\begin{array}{c}\text { BEDD } \\
\left({ }^{\circ} \mathrm{C}\right)\end{array}$ & $\begin{array}{c}\text { Classification } \\
\text { (Gladstones 1992) }\end{array}$ \\
\hline Puget Sound & 318 & Too cold & - \\
Lake Chelan & 838 & Too cold & - \\
Columbia Gorge & 941 & Too cold & - \\
The Rocks District of Milton-Freewater & 969 & Too cold & - \\
Ancient Lakes of the Columbia Valley & 976 & Too cold & - \\
Columbia Valley & 1086 & 1 & Group 1 \\
Walla Walla & 1108 & 1 & Group 2 \\
Wahluke Slope & 1129 & 1 & Group 2 \\
Horse Heaven Hills & 1160 & 1 & Group 3 \\
Red Mountain & 1208 & 2 & Group 4 \\
Naches Heights & 1221 & 2 & Group 5 \\
Rattlesnake Hills & 1286 & 2 & Group 6 8 \\
Yakima Valley & 1339 & 2 & \\
Snipes Mountain & 1590 & 3 & \\
\hline
\end{tabular}

et al. (2010) recommended a classification of grapegrowing regions based on BEDD and suggested that if the $\mathrm{BEDD}$ is below $1000^{\circ} \mathrm{C}$ then the region is too cold for grapes; however, 5 AVAs within our study area had BEDDs lower than $1000^{\circ} \mathrm{C}$, including Puget Sound, Lake Chelan, Columbia Gorge, the Rocks District of Milton-Freewater, and Ancient Lakes of the Columbia Valley. The rest of the classes start at $1000^{\circ} \mathrm{C} \mathrm{BEDD}$, with a range of $200^{\circ} \mathrm{C} B E D D$ for each class (Table 3). Gladstones (1992) reported the wine grape maturity groupings and their corresponding BEDD to ripeness for making dry or semi-sweet table wines (Table 1). Among our chosen AVAs, only Snipes Mountain matched Group 8, for which cultivars such as 'Tarrango', 'Terret Noir', 'Clairette', 'Grenache Blanc', 'Doradillo', 'Biancone' are recommended (Fig. 2a, Table 3).

\subsubsection{GDD}

The calculated GDD indicated that Puget Sound had the lowest accumulated thermal units $\left(948^{\circ} \mathrm{C}\right.$ GDD), while Wahluke Slope had the highest $\left(1662^{\circ} \mathrm{C}\right.$ GDD). The multiple comparisons of GDDs among AVAs indicated that there was no significant difference in the GDD with a 95\% confidence level between Wahluke Slope and the Rocks District of Milton-Freewater. There were also no substantial differences between Red Mountain and Snipes Mountain, or Horse Heaven Hills and Walla Walla, with a $95 \%$ confidence level (Table 4, Table S2). Based on their GDD, the AVAs of this study were primarily categorized (Jackson, 2008) into region I $(\leq 1390)$ and region II (1391 to 1670). Jones et al. (2010) also reported that most of the regions in Washington are categorized as region I, while the Columbia Valley (Oregon) is categorized as region II (Fig. 2b). The higher the heat unit accumulation in a region, the greater the ability to ripen grapes, especially cultivars that mature late in the growing season (Wolfe 1999). Our results also confirm previous reports on the western USA. (Jones et al. 2010).

\subsubsection{HI}

The HI calculated for our study indicated that, among the chosen AVAs, Puget Sound had the lowest (1452), while Snipes Mountain had the highest (2425) (Table 5). The different values for HI indicate that there was a significant difference at the 95\% confidence interval for some AVAs. However, no such differences were found for the following pairs: Ancient Lakes of the Columbia Valley and Yakima Valley, Horse Heaven Hills and Walla Walla, Columbia Valley and Rattlesnake Hills (Table S2). We next categorized the AVAs based on the HI (Jones et al. 2010) (Table 5), with the accepted classification stating that areas with an HI below 1200 are too cold for grapes. The classes start at 1200 , each comprising 300 units. The first HI class (1200 to 1500) is 'very Cool', the second is 'cool' (1500 to 1800), the third is 'temperate' (1800 to 2100), the fourth is 'warm temperate' (2100 to 2400), and the fifth is 'warm' (2400 to 2700). Our results indicated that the majority of AVAs in the study area are located in a 'warm temperate' region (class 4 ) based on their $\mathrm{HI}$ (Fig. 2c).

\subsubsection{LTI}

The LTI was computed for all the AVAs; Puget Sound had the lowest (223.2) while the Rocks District of Milton-Freewater had the highest (336.9) (Table 6). Because this index also considers the latitude of each location, the LTI was significantly differ- 

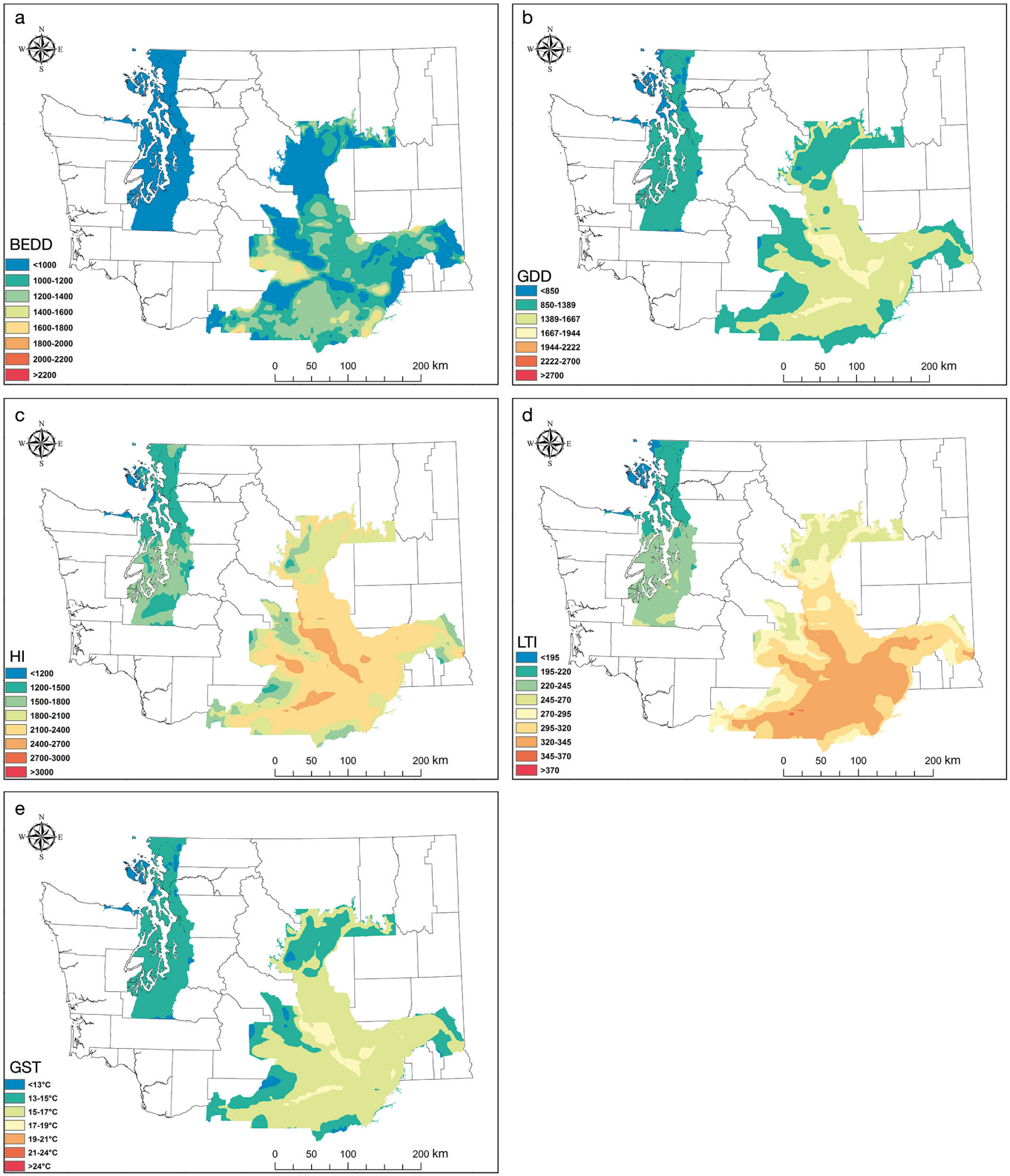

Fig. 2. Key bioclimatic indices primarily dealing with thermal heat unit accumulation for American viticulture areas (AVAs) located in the State of Washington and parts of Oregon. Class limits in legends are not directly comparable. (a) Biologically effective growing degree days (BEDD); (b) growing degree days (GDD); (c) Huglin index (HI); (d) latitude temperature index (LTI); (e) growing season temperature (GST). See Fig. 1 for coordinates 
Table 4. Mean growing degree days (GDD) calculated for each American viticultural area (AVA) based on daily weather data from 1983 to 2012. The classification only pertains to this index

\begin{tabular}{|lcc|}
\hline AVA & $\begin{array}{c}\text { Mean } \\
\text { GDD }\end{array}$ & Region \\
\hline Puget Sound & 948 & I \\
Columbia Gorge & 1089 & I \\
Naches Heights & 1189 & I \\
Lake Chelan & 1329 & I \\
Rattlesnake Hills & 1386 & I \\
Columbia Valley & 1414 & II \\
Yakima Valley & 1488 & II \\
Ancient Lakes & 1525 & II \\
Walla Walla & 1566 & II \\
Horse Heaven Hills & 1566 & II \\
Red Mountain & 1622 & II \\
Snipes Mountain & 1624 & II \\
The Rocks District of Milton-Freewater & 1649 & II \\
Wahluke Slope & 1662 & II \\
\hline
\end{tabular}

Table 5. The calculated Huglin index (HI) for American viticultural areas (AVAs) of the study area. The classification only pertains to this index

\begin{tabular}{|lcc|}
\hline AVA & HI & Classification \\
\hline Puget Sound & 1452 & Very cool \\
Columbia Gorge & 1740 & Cool \\
Naches Heights & 1931 & Temperate \\
Lake Chelan & 2019 & Temperate \\
Columbia Valley & 2124 & Warm temperate \\
Rattlesnake Hills & 2138 & Warm temperate \\
Yakima Valley & 2248 & Warm temperate \\
Ancient Lakes of the & 2248 & Warm temperate \\
Columbia Valley & & \\
Walla Walla & 2274 & Warm temperate \\
Horse Heaven Hills & 2289 & Warm temperate \\
The Rocks District of & 2332 & Warm temperate \\
$\quad$ Milton-Freewater & & \\
Red Mountain & 2362 & Warm temperate \\
Wahluke Slope & 2397 & Warm temperate \\
Snipes Mountain & 2425 & Warm \\
\hline
\end{tabular}

ent (Fig. 2d, Table S2) for all of the AVAs except for Walla Walla and Horse Heaven Hills because that they are located within the same latitude range $\left(45.6^{\circ}\right.$ to $46.2^{\circ} \mathrm{N}$ ).

Yau (2011) also calculated the LTI for the AVAs in this study area, and a comparison between the 2 sets of results showed that the AVA rankings were almost identical for both studies, although the LTIs calculated for our study were generally slightly higher than those reported by Yau (2011). Jackson \& Cherry (1988) reported an LTI grouping based on the cultivars grown in each group. The 4 main groups were: (1) group A with an LTI < 196; (2) group B with an LTI
Table 6. Calculated latitude temperature index (LTI) and corresponding LTI groups for American viticultural areas (AVAs) in the study area using daily weather data from 1983 to 2012. Grouping based on AVA LTIs was also conducted, based on the grouping recommendations from Jackson \& Cherry (1988). LTI grouping does not correspond to groupings in other indices. Examples of cultivars that match the groupings are provided

\begin{tabular}{|lccc|}
\hline AVA & $\begin{array}{c}\text { LTI } \\
\text { group }\end{array}$ & $\begin{array}{c}\text { Examples of } \\
\text { cultivars }\end{array}$ \\
\hline Puget Sound & 223.2 & B & $\begin{array}{c}\text { Riesling, Pinot Noir } \\
\text { and Chardonnay }\end{array}$ \\
Nake Chelan & 269.3 & B & \\
& 281.3 & C & Cabernet Sauvi- \\
& & & $\begin{array}{l}\text { Fnon, Cabernet } \\
\text { Nancherlot, }\end{array}$ \\
Columbia Gorge & 285.3 & C & \\
Ancient Lakes & 299.3 & C & \\
Rattlesnake Hills & 301.8 & C & \\
Columbia Valley & 304.4 & C & \\
Yakima Valley & 312.0 & C & \\
Wahluke Slope & 319.4 & C & \\
Snipes Mountain & 322.3 & C & \\
Red Mountain & 324.8 & C & \\
Horse Heaven Hills & 328.3 & C & \\
Walla Walla & 328.6 & C & \\
The Rocks District & 336.9 & C & \\
of Milton-Freewater & & & \\
\hline
\end{tabular}

ranging from 200 to 275 ; (3) group C with an LTI ranging from 275 to 370 ; and (4) group D with an LTI $>370$. The results of our study indicated that the majority of AVAs in Washington and Oregon are within group C, except for Puget Sound and Lake Chelan (Table 6). Jackson \& Cherry (1988) reported the favored cultivars for group B to be 'Riesling', 'Pinot Noir', and 'Chardonnay', and the favored cultivars for group C are 'Cabernet Sauvignon', 'Cabernet Franc', 'Merlot', 'Malbec', 'Sauvignon Blanc', and 'Semillion'. This classification can thus be used as a tool for assisting in the selection of cultivars based on their LTI groupings.

\subsubsection{GST}

The GST for all the AVAs was greater than $13.7^{\circ} \mathrm{C}$. Puget Sound had the lowest GST $\left(13.7^{\circ} \mathrm{C}\right)$ while the Rocks District of Milton-Freewater had the highest $\left(16.9^{\circ} \mathrm{C}\right)$ (Table 7; Table S2). Comparison of the mean 
Table 7. Mean growing season temperature (GST) calculated for each American viticulture area (AVA) in the study area from 1983 to 2012, and some examples of possible grape cultivars that match the climate maturity groupings

\begin{tabular}{|lccl|}
\hline AVA & $\begin{array}{c}\text { Mean } \\
\text { GST } \\
\left({ }^{\circ} \mathrm{C}\right)\end{array}$ & $\begin{array}{c}\text { Climate } \\
\text { maturity } \\
\text { grouping }\end{array}$ & Examples recommended of grape cultivars \\
\hline Puget Sound & 13.7 & Cool (1) & $\begin{array}{c}\text { Riesling, Muller-Thurgau, Pinot Gris, Gewürztraminer, } \\
\text { Pinot Noir, Chardonnay, Sauvignon Blanc }\end{array}$ \\
Columbia Gorge & 14.0 & Cool (1) & \\
Naches Heights & 14.4 & Cool (1) & \\
Lake Chelan & 15.1 & Intermediate (2) & Riesling, Pinot Gris, Gewürztraminer, Pinot Noir, \\
& & & Chardonnay, Sauvignon Blanc, Semillon, Cabernet \\
& & & Franc, Tempranillo, Merlot, Malbec, Syrah, Viognier, \\
Cabernet Sauvignon & & & \\
Rattlesnake Hills & 15.5 & Intermediate (2) & \\
Columbia Valley & 15.6 & Intermediate (2) & \\
Yakima Valley & 16.0 & Intermediate (2) & \\
Ancient Lakes of the Columbia Valley & 16.2 & Intermediate (2) & \\
Horse Heaven Hills & 16.4 & Intermediate (2) & \\
Walla Walla & 16.5 & Intermediate (2) & \\
Red Mountain & 16.7 & Intermediate (2) & \\
Snipes Mountain & 16.7 & Intermediate (2) & \\
Wahluke Slope & 16.9 & Intermediate (2) & \\
The Rocks District of Milton-Freewater & 16.9 & Intermediate (2) & \\
& & & \\
& & &
\end{tabular}

GST for each AVA revealed that there was a substantial difference in GST among the AVAs, except for Red Mountain and Snipes Mountain, as well as the Rocks District of Milton-Freewater and Wahluke Slope, which only had small differences at the 95\% confidence level.

Additional classifications have been made based on the average GST as a means of determining grape maturity groupings and cultivars (Jones 2007, Jones et al. 2010, Yau 2011). These groupings start at average GSTs of $13^{\circ} \mathrm{C}$ and end at $24^{\circ} \mathrm{C}$. The 4 major maturity groups within this range are: (1) the cool climate maturity group ranging from 13 to $15^{\circ} \mathrm{C}_{i}(2)$ the intermediate climate maturity group ranging from 15 to $17^{\circ} \mathrm{C}_{i}(3)$ the warm climate maturity group ranging from 17 to $19^{\circ} \mathrm{C}$; and (4) the hot climate maturity group ranging from 19 to $24^{\circ} \mathrm{C}$. Based on the calculated GST, each AVA in our study can be categorized as belonging in either climate maturity group 1 or 2 (Fig. 2e, Table 7). There are also several cultivars associated with these climate maturity groupings (Jones 2007, Yau 2011). The application of GST can help to distinguish the climate maturity groupings for AVAs, thereby enabling better cultivar recommendations for each specific climate maturity grouping (Fig. 2e, Table 7).

\subsection{Bioclimatic indices focusing on length of growing season}

\subsubsection{FFD}

The calculation of FFD for each AVA showed that Naches Heights had the lowest number of FFD (146 d) and Puget Sound had the highest (230 d). Red Mountain and Wahluke Slope did not show a significant difference in FFD at the 95\% confidence level (Table S2), implying that the average growing season length for these regions is similar. This information can help decision-makers select cultivars for each specific AVA that will complete their growing cycles prior to the first freeze in fall, and start their activity after the last frost in the spring.

Previous studies have indicated that a region requires a minimum FFD of $180 \mathrm{~d}$ to be considered optimal for grape production (Prescott 1965, Rosenberg et al. 1983, Becker 1985, Jackson \& Cherry 1988, Yau et al. 2013). Among our selected AVAs, Wahluke Slope, Walla Walla, the Rocks District of Milton-Freewater, and Puget Sound all had FFD that were equal to or greater than 180 d. Knowledge of the ranking of AVAs based on their FFD is important for the assignment of early or late cultivars in these regions. The remaining 
AVAs with an FFD of less than $180 \mathrm{~d}$ have already been established, and they are still able to produce marketable grapes. However, this may be due in part to interventions such as wind machines, and other frost protection measures. Still, the reported optimal growing season length for regions with a proven record of sustainable grape production should be updated based on the chances that the growers are willing to take in a region that has a higher risk of damage due to low temperature (Fig. 3a).

\subsubsection{GSS}

GSS was also calculated for the AVAs in our study. The Columbia Gorge had the lowest GSS (0.82), while the Rocks District of Milton-Freewater had the highest (0.92) (Fig. 3b). All AVAs had a GSS higher than 0.8 (Table 8), indicating that for $80 \%$ of the
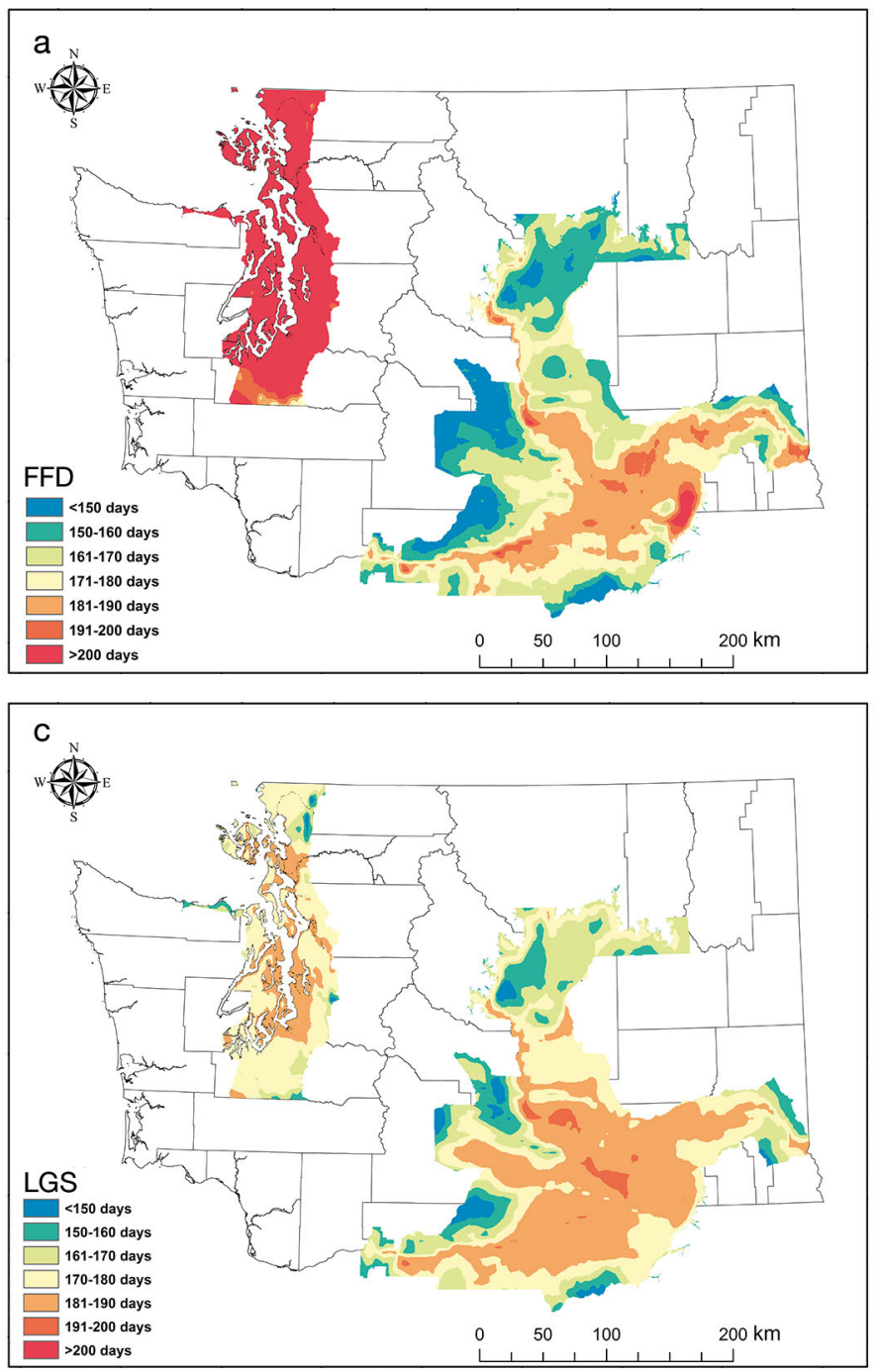

period from April to September the air temperature is higher than $10^{\circ} \mathrm{C}$. Santos et al. (2012) reported that a GSS higher than $90 \%$ is required for a region to be considered suitable for grape production, in order to satisfy the heat requirement of grapevines. Although, the GSS calculated for half of the AVAs in our study was lower than $90 \%$, they are still suitable for viticulture because they have a GSS ranging from $80 \%$ to $90 \%$. Regions with a lower GSS (Table 8) in Washington and northeastern Oregon are similar to viticultural regions in Western Europe such as Burgundy, Champagne, and the Mosel and Rhine Valleys of Germany (Malheiro et al. 2012, Santos et al. 2012).

\subsubsection{LGS}

The calculated LGS ranged from 164 to $189 \mathrm{~d}$. Naches Heights had the lowest LGS (164 d) while the

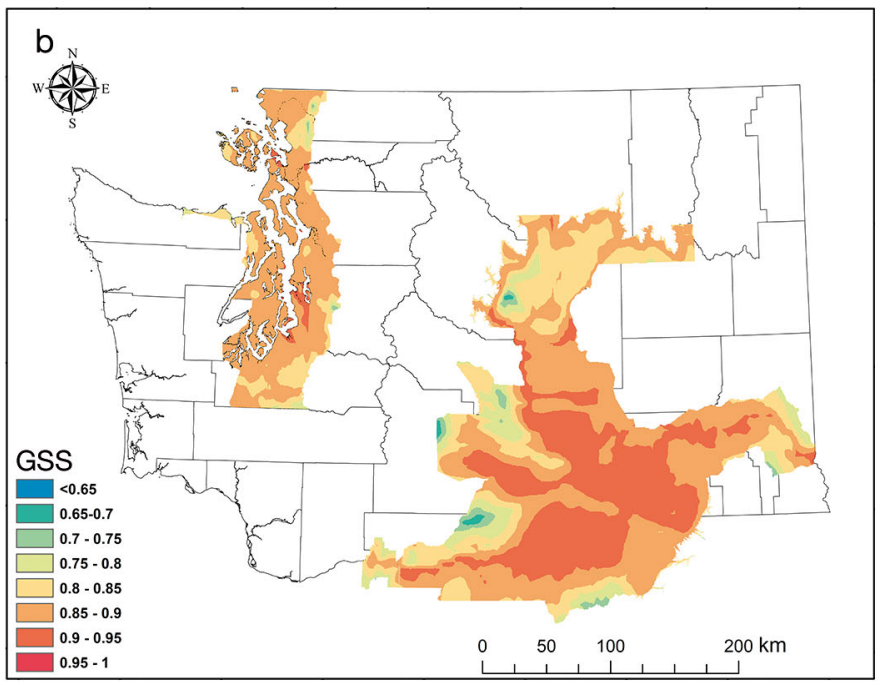

Fig. 3. Key bioclimatic indices focusing on the length of growing season for American viticulture area (AVAs) located in the State Washington and parts of Oregon. Class limits are not directly comparable. (a) Frost free days (FFD); (b) growing season suitability (GSS); (c) length of growing season (LGS). See Fig. 1 for coordinates 
Table 8. The range of growing season suitability (GSS) calculated and averaged over a period of $30 \mathrm{yr}$ based on daily weather data from 1983 to 2012. The classification only pertains to this index

\begin{tabular}{|lcc|}
\hline AVA & GSS & $\begin{array}{c}\text { Preference } \\
\text { based on GSS }\end{array}$ \\
\hline Columbia Gorge & 0.82 & Suitable \\
Naches Heights & 0.83 & Suitable \\
Lake Chelan & 0.86 & Suitable \\
Puget Sound & 0.86 & Suitable \\
Rattlesnake Hills & 0.87 & Suitable \\
Columbia Valley & 0.87 & Suitable \\
Yakima Valley & 0.89 & Suitable \\
Ancient Lakes of & 0.90 & Most suitable \\
the Columbia Valley & & \\
Horse Heaven Hills & 0.90 & Most suitable \\
Walla Walla & 0.91 & Most suitable \\
Wahluke Slope & 0.91 & Most suitable \\
Snipes Mountain & 0.92 & Most suitable \\
Red Mountain & 0.92 & Most suitable \\
The Rocks District of & 0.92 & Most suitable \\
Milton-Freewater & & \\
\hline
\end{tabular}

Rocks District of Milton-Freewater had the highest (189 d). Warmer regions located at lower elevations tended to have a higher LGS compared with colder regions at higher elevations (Fig. 3c). However, since this index essentially uses concepts similar to FFD, we evaluated AVAs by checking both indices simultaneously. In comparisons of all AVAs, some had similar LGS and FFD (Table 9) while others showed substantial differences. This resulted in 2 conditions. When FFD is larger than LGS, the risk of frost is low and there is a long period between the last frost in spring and the first frost in fall. However, if the selected cultivars in regions with these types of conditions are not able to complete their growth and development cycle within the LGS, they may not mature properly and the grapes might not be of optimal quality. When FFD is less than LGS, which is the dominant case for the majority of AVAs in our study (Table 9), the risk of frost during the growing season is higher, and because of this, it is better to adjust the LGS to be equal to the FFD.

All of the AVAs in our study match the second condition, except for Puget Sound, Walla Walla, and the Rocks District of Milton-Freewater (Fig. 3c). In regions with shorter growing seasons, grapes may be unable to complete their full growth cycles, while the chilling period could be insufficient for the Puget Sound AVA. This index can be integrated with other indices to more accurately match specific cultivars
Table 9. Calculated length of growing season (LGS) for all the American viticulture areas (AVAs) in the study area and their corresponding frost free days (FFD). Adjusted LGS based on the lowest value of either LGS or FFD

\begin{tabular}{|lccc|}
\hline AVA & LGS & FFD & $\begin{array}{c}\text { Adjusted } \\
\text { LGS }\end{array}$ \\
\hline Naches Heights & 164 & 146 & 146 \\
Columbia Gorge & 165 & 164 & 164 \\
Lake Chelan & 169 & 166 & 166 \\
Rattlesnake Hills & 174 & 157 & 157 \\
Columbia Valley & 175 & 168 & 168 \\
Puget Sound & 176 & 230 & 176 \\
Ancient Lakes of & 179 & 171 & 171 \\
$\quad$ the Columbia Valley & & & \\
Yakima Valley & 179 & 164 & 164 \\
Horse Heaven Hills & 183 & 178 & 178 \\
Walla Walla & 184 & 189 & 184 \\
Wahluke Slope & 185 & 180 & 180 \\
Snipes Mountain & 186 & 166 & 166 \\
Red Mountain & 186 & 179 & 179 \\
The Rocks District of & 189 & 203 & 189 \\
$\quad$ Milton-Freewater & & & \\
\hline
\end{tabular}

with regions that have shorter growing seasons, thereby providing useful information to assist decision-makers in cultivar selection.

\subsection{Bioclimatic indices focusing on minimum temperature}

\subsection{1. $\mathrm{CI}$}

Our calculation of the CI indicated that Naches Heights had the lowest average $\left(6.8^{\circ} \mathrm{C}\right)$ while the Rocks District of Milton-Freewater had the highest $\left(10.2^{\circ} \mathrm{C}\right)$. Comparison of the $\mathrm{CI}$ among all the AVAs showed a significant difference among most of the AVAs at a 95\% confidence level, except for AVA pairs Ancient Lakes and Puget Sound, Horse Heaven Hills and Red Mountain, Columbia Valley and Snipes Mountain, and Yakima Valley and Lake Chelan (Table S2, Fig. 4a.). Knowledge of regions with similar CIs can aid growers and decision-makers in a more accurate allocation of cultivars to specific regions, thus improving the potential quality of the grapes that are being produced. Based on the CI classifications discussed by Tonietto \& Carbonneau (2004), all AVAs in our study are categorized as CI+2 regions with a $\mathrm{CI} \leq 12^{\circ} \mathrm{C}$. This category of viticultural climate has a great potential for producing quality grapes when the thermal heat units in the region are 

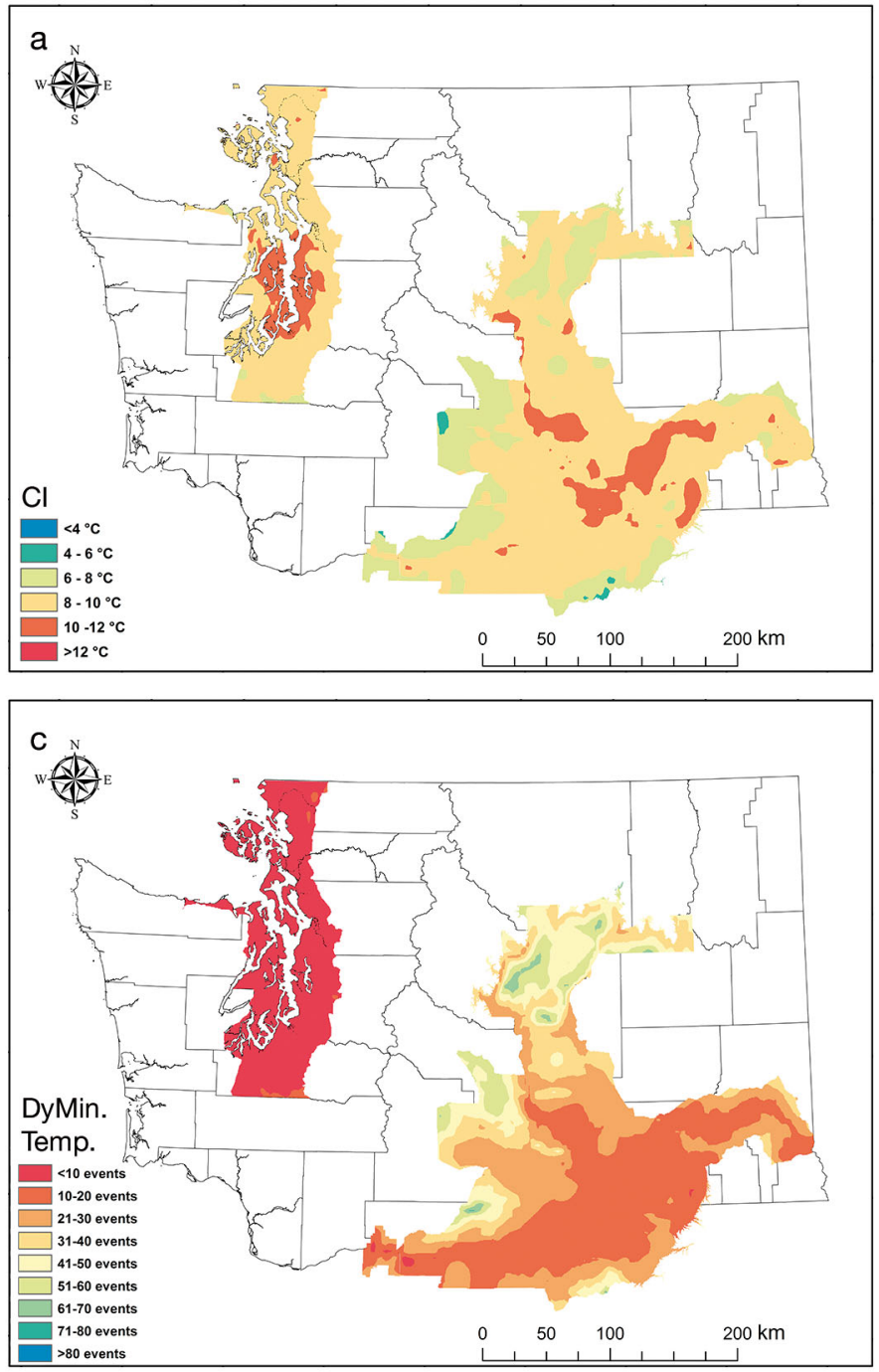

sufficient (Tonietto \& Carbonneau 2004). A lower CI causes a lower rate of metabolism for aromatic materials and pigments during the night.

\subsubsection{MTA}

The calculations indicated that Puget Sound had the lowest MTA $\left(11.4^{\circ} \mathrm{C}\right)$ among all the AVAs while Snipes Mountain had the highest $\left(18.1^{\circ} \mathrm{C}\right)$. Multiple comparisons among the AVAs indicated that there was no significant difference in the MTAs of Columbia Gorge, Colombia Valley, Red Mountain, and Wahluke Slope at a $95 \%$ confidence level (Table S2, Fig. 4b). Ancient Lakes of the Columbia Valley, Horse Heaven Hills, and Walla Walla had no significant difference at the 95\% confidence level. Lake Chelan and the Rocks District of Milton-Freewater

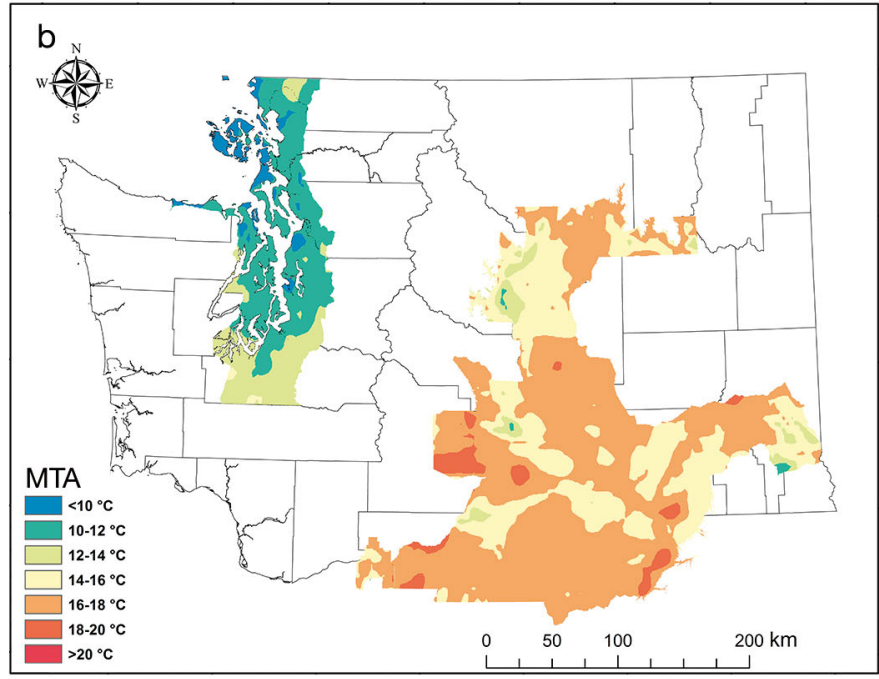

Fig. 4. Key bioclimatic indices used in calculation of minimum temperature for American viticulture area (AVAs) located in the State of Washington and parts of Oregon. Class limits not directly comparable. (a) Cool night index (CI); (b) mean thermal amplitude (MTA); (c) dynamic minimum temperature (DyMin.Temp.). See Fig. 1 for coordinates

also had no significant difference at the $95 \%$ confidence level. This index has been shown to influence the quality of grapes, including grape composition, flavor, and aroma (Mullins et al. 1992, Ramos et al. 2008, Montes et al. 2012). Therefore, if the same management and irrigation strategies are used, AVAs with similar MTA can potentially produce grapes with many similar quality traits. However, further assessments are needed to evaluate fruit quality traits in AVAs with comparable bioclimatic ranges.

\subsubsection{DyMin.Temp.}

The number of events when the minimum air temperature dropped below a certain temperature threshold that changes across multiple seasons were calculated for all AVAs for a period of $30 \mathrm{yr}$. Puget 
Table 10. Number of incidents for each American viticulture area (AVA) in the study area when the minimum air temperature drops below a cold hardiness threshold or cold damage index (CDI) calculated for 5, 10, 20, and $30 \mathrm{yr}$ out of the historical weather data. The number of events for a century was calculated based on the CDI for $30 \mathrm{yr}$

\begin{tabular}{|lccccc|}
\hline \multirow{2}{*}{ AVA } & \multicolumn{5}{c}{ CDI } \\
\cline { 2 - 6 } & 5 yr & 10 yr & 20 yr & 30 yr & century \\
\hline Puget Sound & 0 & 1 & 1 & 1 & 5 \\
Red Mountain & 4 & 5 & 13 & 15 & 49 \\
The Rocks District & 5 & 5 & 5 & 22 & 74 \\
$\quad$ of Milton-Freewater & & & & & \\
Wahluke Slope & 6 & 7 & 13 & 18 & 59 \\
Walla Walla & 7 & 9 & 47 & 16 & 52 \\
Snipes Mountain & 7 & 12 & 25 & 33 & 112 \\
Horse Heaven Hills & 9 & 12 & 20 & 23 & 78 \\
Yakima Valley & 11 & 17 & 33 & 46 & 155 \\
Ancient Lakes of & 11 & 13 & 23 & 30 & 99 \\
the Columbia Valley & & & & & \\
Lake Chelan & 13 & 16 & 30 & 38 & 126 \\
Columbia Gorge & 13 & 23 & 43 & 56 & 187 \\
Columbia Valley & 14 & 20 & 36 & 48 & 161 \\
Rattlesnake Hills & 15 & 23 & 13 & 72 & 239 \\
Naches Heights & 30 & 47 & 86 & 119 & 397 \\
\hline
\end{tabular}

Sound was determined to have the lowest number of events (3) (Table S2), while Naches Heights had the highest number of events (45) (Fig. 4c). The multiple comparison of the DyMin.Temp. showed significant differences between AVAs (Table S2) except for Ancient Lakes of the Columbia Valley and Rattlesnake Hills besides Red Mountain and Columbia Gorge. The amount of damage caused by exposure to a low temperature depends on where individual plants are in their phenological stages, showing that both temporal and spatial analysis of this index are critical for both the Naches Heights and Puget Sound AVAs. The temporal distribution of events was focused on April, with no incidents occurring during the summer months (June, July, and August). The concentration of most of the events in April might be partially due to the assumptions made for the calculation of the index, which set the April low temperature threshold to a value of 0 .

Our study is the first to consider a dynamic minimum temperature rather than a fixed minimum temperature. Although this index is not sufficient to fully categorize grape-growing regions, it can be used in conjunction with other indices to better explore climate variability and weather extremes in viticultural regions. Future studies should evaluate the risks associated with viticulture in regions that suffer from frequent freezes, and evaluate each region based on its resilience, adaptability, and technological advancement.

\subsubsection{CDI}

The total number of events when the minimum temperature dropped below a dynamic threshold (Bud $\mathrm{LT}_{50}$ ) was determined for 5, 10, 20, and $30 \mathrm{yr}$ periods and projected for $100 \mathrm{yr}$ (Table 10). Puget Sound proved to have the lowest number of events $(0$ within $5 \mathrm{yr}$ and 1 for up to $30 \mathrm{yr}$ ), while the highest number of events was found for Naches Heights (30, 47,86 , and 119 events for 5, 10, 20, and $30 \mathrm{yr}$, respectively) (Fig. 5a-d). Our comparison of the CDI analysis indicated that there was a significant difference between the Puget Sound results and the other AVAs (Table S2).

The impact of CDI events for a given location depends on various factors, such as the duration of a cold spell, economic profitability of the vineyard, availability of affordable technologies, and the mitigation of the grower to the risks associated with potential crop loss. Discussing the limiting ranges of CDI events is beyond the scope of this paper and needs further investigation. Therefore, the results presented here can be used as a foundation for future studies using this index as an effective tool for the determination of regions that have a high number of CDI events.

\subsection{Bioclimatic indices focusing on precipitation}

Our results indicated that, for the majority of AVAs, most precipitation occurs during winter and early spring $(\sim 60 \%)$, except for the Columbia Gorge $(\sim 40 \%)$. This information can be beneficial for decision-makers and growers in determining their options for supplemental irrigation. Furthermore, the amount of precipitation that finally reaches a grapevine's root zone is generally lower than the recorded precipitation, due to the partial interception of raindrops by the canopy and vineyard cover crops, as well as evaporation at the surface. Therefore, the actual available water to the plants is even lower than the calculated values based only on precipitation. Hence, when assessing the precipitation of various AVAs, 2 questions must first be answered: (1) does the region require supplementary irrigation and (2) if the region requires supplementary irrigation, does a proposed site for a vineyard have access to water and rights to use it? 

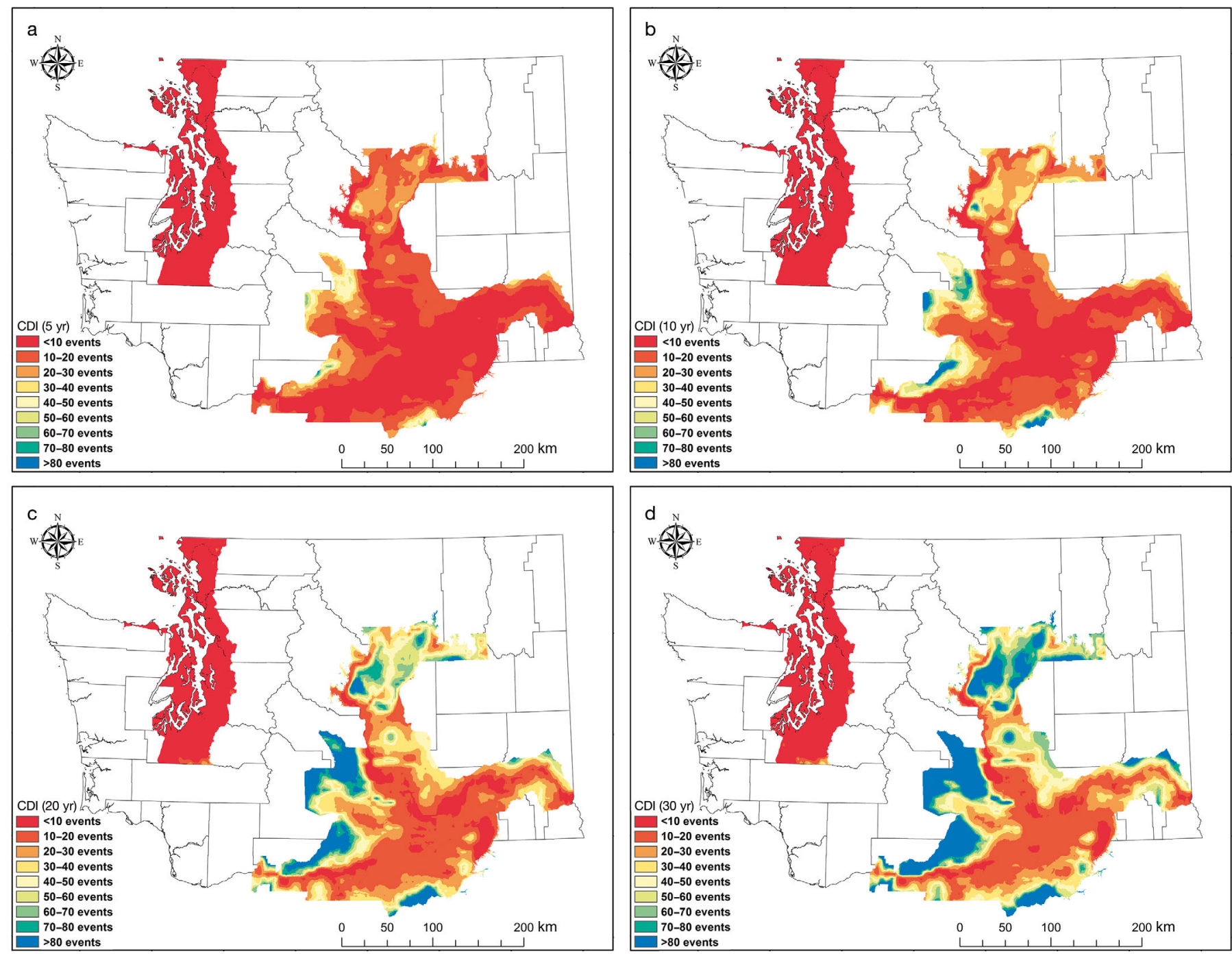

Fig. 5. Cold damage index (CDI) for American viticulture area (AVAs) located in the State of Washington and parts of Oregon for (a) 5 yr; (b) $10 \mathrm{yr}_{\text {; (c) }} 20 \mathrm{yr}$; (d) $30 \mathrm{yr}$. See Fig. 1 for coordinates

\subsubsection{GSP}

GSP was computed for all the AVAs. Snipes Mountain had the lowest GSP (52 mm) while Puget Sound had the highest $(332 \mathrm{~mm})$ (Table 11). The GSP for Puget Sound was notably different when compared to the other AVAs (Table S2). The GSPs for Columbia Gorge and Walla Walla also showed significant difference compared with the other AVAs at the 95\% confidence level (Fig. 6a, Table S2). This index provides an accurate means of determining the general suitability of a region for viticulture (Santos et al. 2012), especially in locations where irrigation is not an option. If a region has a GSP that is less than $200 \mathrm{~mm}$, it is regarded as extremely dry; while if the GSP is greater than $600 \mathrm{~mm}$, it is regarded as excessively humid. All AVAs that were assessed in our study had a GSP lower than 200 $\mathrm{mm}$, except for the Columbia Gorge and Puget Sound (Fig. 6a).

\subsubsection{OutGSP}

OutGSP provides further insight into the available soil water at the start of the growing season. Our results indicated that Wahluke Slope had the lowest OutGSP $(73 \mathrm{~mm}$ ) and Puget Sound had the highest $(415 \mathrm{~mm})$ (Fig. 6b, Table 11). Preference is generally given to regions that receive the majority of their precipitation during the winter, thus providing the plants in these regions with sufficient soil water prior 
Table 11. Growing season precipitation (GSP), out-of-growing-season precipitation (OutGSP), and average total annual precipitation for the American viticultural areas (AVAs) in the study area and their respective percentage of the total precipitation

\begin{tabular}{|lccccc|}
\hline AVA & $\begin{array}{c}\text { GSP } \\
(\mathrm{mm})\end{array}$ & $\begin{array}{c}\text { OutGSP } \\
(\mathrm{mm})\end{array}$ & $\begin{array}{c}\text { Total } \\
\text { precipitation } \\
(\mathrm{mm})\end{array}$ & $\begin{array}{c}\text { GSP } \\
(\%)\end{array}$ & $\begin{array}{c}\text { OutGSP } \\
(\%)\end{array}$ \\
\hline Snipes Mountain & 52 & 78 & 130 & 40 & 60 \\
Rattlesnake Hills & 57 & 90 & 147 & 39 & 61 \\
Wahluke Slope & 58 & 73 & 132 & 44 & 56 \\
Ancient Lakes of & 59 & 78 & 137 & 43 & 57 \\
the Columbia Valley & & & & & \\
Red Mountain & 61 & 86 & 147 & 41 & 59 \\
Yakima Valley & 63 & 87 & 150 & 42 & 58 \\
Horse Heaven Hills & 65 & 96 & 160 & 40 & 60 \\
Columbia Valley & 81 & 120 & 201 & 40 & 60 \\
Lake Chelan & 83 & 108 & 191 & 44 & 56 \\
Naches Heights & 96 & 112 & 208 & 46 & 54 \\
The Rocks District of & 98 & 185 & 283 & 35 & 65 \\
$\quad$ Milton-Freewater & & & & & \\
Walla Walla & 112 & 197 & 309 & 36 & 64 \\
Columbia Gorge & 262 & 195 & 457 & 57 & 43 \\
Puget Sound & 332 & 415 & 747 & 44 & 56 \\
\hline
\end{tabular}

2014). However, downy mildew is not a cause of concern since the pathogen does not yet occur, mainly due to unfavorable weather conditions for this pathogen in Washington.

\subsection{Bioclimatic index focusing on wind speed}

The WSI was calculated for the AVAs located in our study area, with Red Mountain proving to be the least windy (16 incidents) and Snipes Mountain the windiest (56 incidents) (Table S2). Red Mountain and Snipes Mountain had significant differences at the $95 \%$ confidence level for WSI compared to other AVAs. Wind speed is influenced by the complexity of topographic elements in a region as well as the variability in the thermal properties of different land cover types, leading to a thermal gradient. This index cannot be used as a stand-

to the start of growth and development in early spring (Jackson 2008).

Gladstones (1992) reported an average GSP of 53 and $70 \mathrm{~mm}$ for Fresno and San Jose, California. The calculated GSP for the AVAs in the current study showed that Snipes Mountain, Rattlesnake Hills, Wahluke Slope, Ancient Lakes, Red Mountain, Yakima Valley, and Horse Heaven Hills are within the same range of GSP reported for these locations in California (Gladstones 1992). However, the OutGSP for these AVAs is lower than the values reported for Fresno $(178 \mathrm{~mm})$ and San Jose $(300 \mathrm{~mm})$. It is important to evaluate the potential of a region based on both the GSP and OutGSP in order to better understand the options for rainfed viticulture versus irrigated viticulture.

\subsubsection{HyI}

Among all the AVAs, Wahluke Slope had the lowest HyI (833.9) and Puget Sound had the highest (3144.6) (Table S2, Fig. 6c). The multiple comparison indicated that Puget Sound and Columbia Gorge had a significant difference when compared to all other AVAs and between themselves. HyI indicates the potential risk of downy mildew (Santos et al. 2012) in a region as well as the water availability (Fraga et al. alone tool for climate zoning. However, it can serve as a surrogate to help growers and decision-makers gain valuable knowledge about a site. In addition, it can help them make more effective decisions regarding management strategies such as installing a windbreak. Future studies can use this index to focus on locations that have higher WSI scores and to conduct more detailed studies on the impact of wind speed on vines, such as physical damage, shoot growth, and photosynthesis disruption.

\subsubsection{Meso-climate and terrain features}

The similarities and differences between the AVAs based on their bioclimatic indices can be described by the factors that impact the meso-climate, specifically the topographic features and complexity of the terrain in a region, including the elevation, slope, and aspect of the sites. The effect of elevation on minimum temperature was clearly captured for Naches Heights, as this AVA has the highest elevation of all AVAs (543 $\mathrm{m})$, and the lowest CI, lowest FFD, highest CDI, and highest DyMin.Temp. Puget Sound had the lowest elevation of all AVAs, and the highest CI, highest FFD, lowest CDI, and lowest DyMin.Temp.

Weather parameters such as relative humidity also indirectly impact the behavior of bioclimatic indices. 

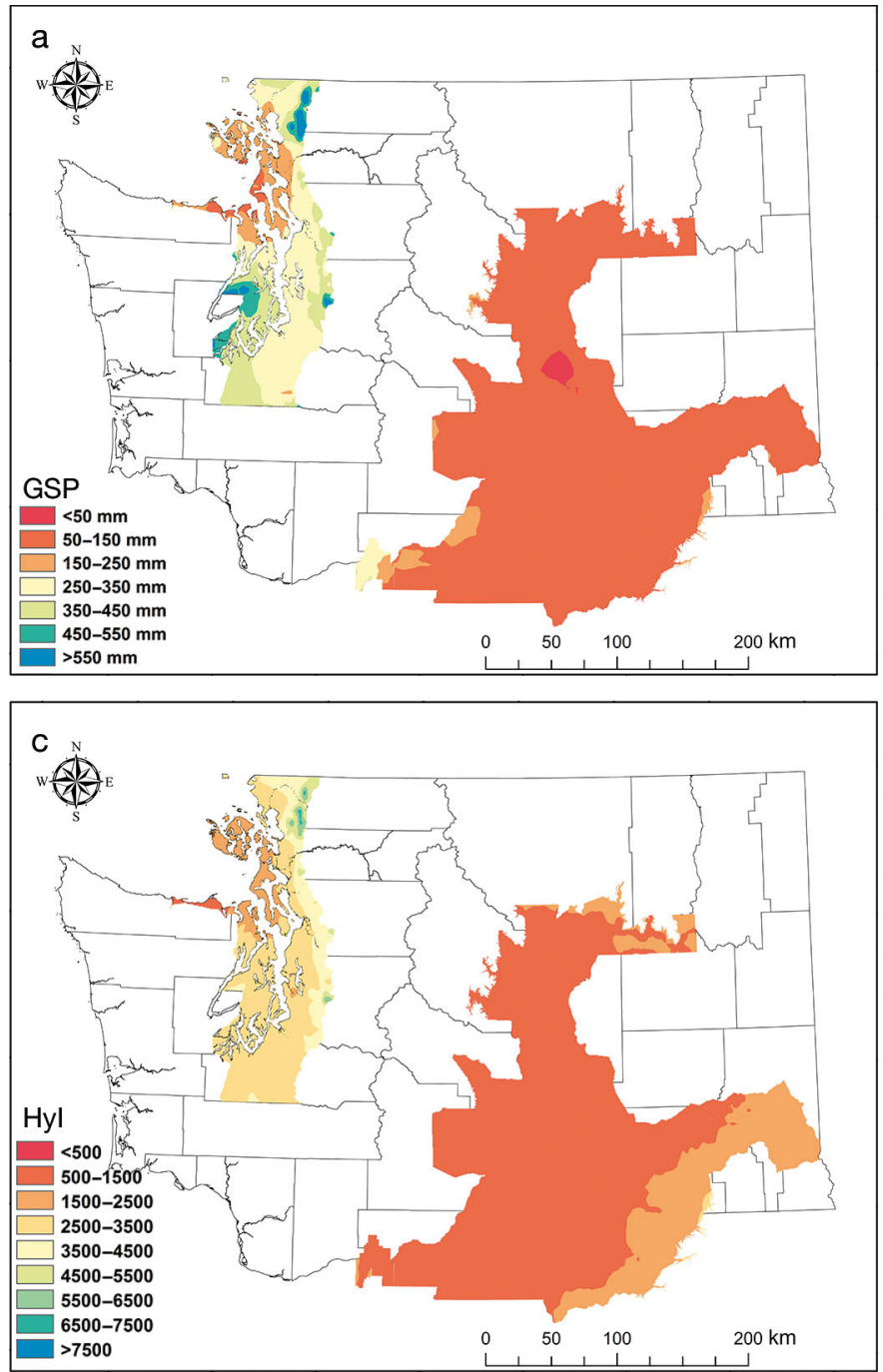

Hence, for an index such as HyI, the value increases in wet regions such as Puget Sound, where the relative humidity is much higher compared to other regions located to the east of the Cascade Mountains. Consequently, future studies should relate the impact of relative humidity on the overall dynamics of bioclimatic indices on a local scale within each AVA. There is also a need for development of a management framework based on the current cultural practices that are implemented in AVAs with similar climate groupings.

The derived zones based on the bioclimatic indices confirmed the previous reports (Jones et al. 2010) on the zoning of the AVAs in the study area. The derived ranges for GDD, HI, and BEDD for our study area completely aligned with the ranges reported by Jones et al. (2010) for the same study area. The spatial and temporal resolution of the data that was used in this current study played an

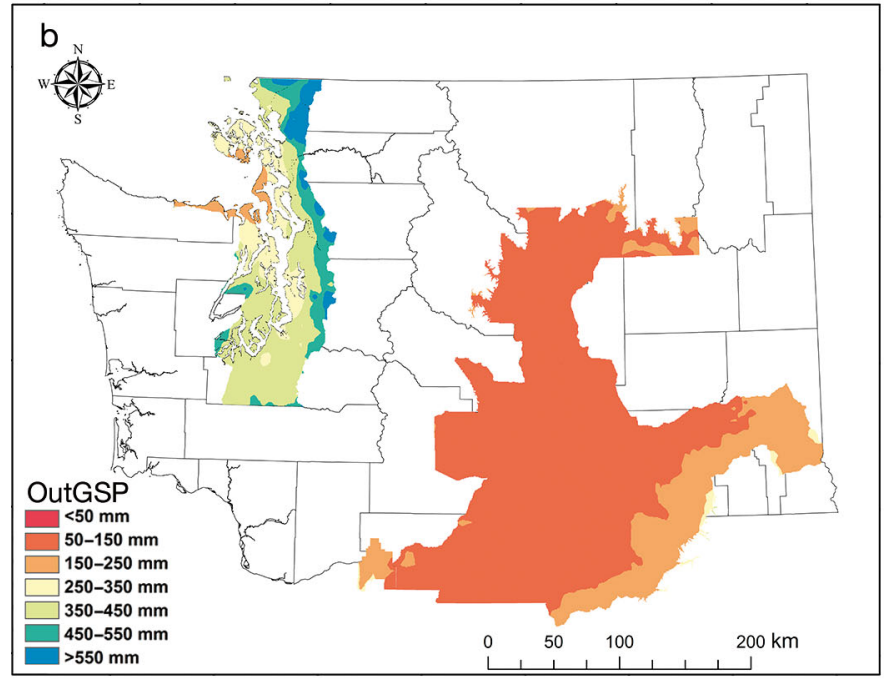

Fig. 6. Key bioclimatic indices focused on the precipitation of American viticulture area (AVAs) located in the State of Washington and parts of Oregon. Class limits are not directly comparable for the hydrothermic Index. (a) Growing season precipitation (GSP); (b) out-of-growing-season precipitation (OutGSP); (c) hydrothermic index (HyI). See

Fig. 1 for coordinates

important role in capturing the dynamics of weather in each AVA. Hence, the results of this study could potentially improve our ability to delineate cultivar suitability zones within each AVA in the study area.

\section{CONCLUSIONS}

This study categorized the AVAs located in the State of Washington and parts of Oregon based on the dynamics of bioclimatic indices that were evaluated for a $30 \mathrm{yr}$ period. Several new bioclimatic indices were introduced, including CDI, DyMin.Temp., and WSI. Future studies should focus on the development and improvement of bioclimatic indices based on recent advancements in sensor technology and the availability of finer resolution spatial and temporal data. 
Acknowledgements. This research was partially supported by Washington State University's AgWeatherNet Program, the Northwest Center for Small Fruits Research, and an IBM Fellowship awarded to G.B. The authors thank the University of Idaho gridded surface meteorological data (UI GSM) for providing access to the raw weather data that were used in this study. The authors are also grateful to Dr. Carol Wilkerson for her help reviewing this manuscript.

\section{LITERATURE CITED}

Abatzoglou JT (2013) Development of gridded surface meteorological data for ecological applications and modelling. Int J Climatol 33:121-131

AgriMet (Cooperative Agricultural Weather Data) (2011) www.usbr.gov/pn/agrimet/wxdata.html (accessed 16 September, 2017)

AgWeatherNet (2011) Daily weather data. Washington State University, Prosser, Washington. http://weather.wsu.edu (accessed 23 February, 2016)

Allen RG, Pereira LS, Raes D, Smith M (1998) Crop evapotranspiration-Guidelines for computing crop water requirements - FAO Irrigation and drainage paper 56 . FAO, Rome

Amerine MA, Winkler AJ (1944) Composition and quality of musts and wines of California grapes. Hilgardia 15: 493-675

Anderson JD, Jones GV, Tait A, Hall A, Throught MCT (2012) Analysis of viticulture region climate structure and suitability in New Zealand. J Int Sci Vigne Vin 46:149-165

Badr G, Hoogenboom G, Moyer M, Keller M, Rupp R, Davenport J (2018) Spatial suitability assessment for vineyard site selection based on fuzzy logic. Precis Agric 2018:1-22

Becker N (1985) Site selection for viticulture in cooler climates using local climatic information. In: Proc International Symposium on Cool Climate Viticulture and Enology. Oregon State University Technical Publication 7628 : 20-34

Blanco-Ward D, Queijeiro JMG, Jones GV (2007) Spatial climate variability and viticulture in the Miño River Valley of Spain. Vitis 46:63-70

Branas J (1974) Viticulture. Imprimerie Déhan, Montpellier

Campbell-Clause JM (1998) Stomatal response of grapevines to wind. Aust J Exp Agric 38:77-82

Clark JR, Wolf TK, Warren MK (1996) Thermal analysis of dormant buds of two muscadine grape cultivars and of Vitis labrusca L. 'Mars'. HortScience 31:79-81

Conceição MAF, Tonietto J (2005) Climatic potential for wine grape production in the tropical north region of Minas Gerais State, Brazil. Rev Bras Frutic 27:404-407

Daly C, Halbleib M, Smith JL, Gibson WP and others (2008) Physiographically sensitive mapping of temperature and precipitation across the conterminous United States. Int J Climatol 28:2031-2064

Davenport JR, Keller M, Mills LJ (2008) How cold can you go? Frost and winter protection for grape. HortScience 43:1966-1969

* Dry PR, Reed S, Potter G (1989) The effect of wind on the performance of cabernet franc grapevines. Acta Hortic 143-146

ESRI (Environmental Systems Research Institute) (2015) ArcGIS Desktop10.2. ESRI Academy Redlands, CA

Fennell A (2004) Freezing tolerance and injury in grape- vines. J Crop Improv 10:201-235

Ferguson JC, Tarara JM, Mills LJ, Grove GG, Keller M (2011) Dynamic thermal time model of cold hardiness for dormant grapevine buds. Ann Bot 107:389-396

Ferguson JC, Moyer MM, Mills LJ, Hoogenboom G, Keller M (2014) Modeling dormant bud cold hardiness and budbreak in twenty-three Vitis genotypes reveals variation by region of origin. Am J Enol Vitic 65:59-71

* Fraga H, Malheiro AC, Moutinho-Pereira J, Santos JA (2013) Future scenarios for viticultural zoning in Europe: ensemble projections and uncertainties. Int J Biometeorol 57:909-925

Fraga H, Malheiro AC, Moutinho-Pereira J, Santos JA (2014) Climate factors driving wine production in the Portuguese Minho region. Agric For Meteorol 185:26-36

Freeman BM, Kliewer WM, Stern P (1982) Influence of windbreaks and climatic region on diurnal fluctuation of leaf water potential, stomatal conductance, and leaf temperature of grapevines. Am J Enol Vitic 33:233-236

Gladstones J (1992) Viticulture and Environment. Winetitles, Adelaide

* Hall A, Jones GV (2010) Spatial analysis of climate in wine grape-growing regions in Australia. Aust J Grape Wine Res 16:389-404

Hamilton RP (1988) Wind effects on grape vines. In: Smart RE, Thornton RJ, Rodriques SB, Young JE (eds) Proc 2nd International Symposium for Cool Climate Viticulture and Oenology, January 1988, Auckland. New Zealand Society of Viticulture and Oenology, Wine Institute of New Zealand, Auckland, p 65-68

Hidalgo L (2002) Tratado de viticultura general. Ediciones Mundi-Prensa, Madrid

Huglin P (1978) Nouveau mode d'évaluation des possibilités héliothermiques d'un milieu viticole. CR Acad Agric Fr 64:1117-1126

Huglin P, Schneider C (1998) Biologie et écologie de la vigne. Lavoisier, Paris

Hunter JJ, Bonnardot V (2011) Suitability of some climatic parameters for grapevine cultivation in South Africa, with focus on key physiological processes. S Afr J Enol Vitic 32:137-154

Jackson RS (2008) Wine science principles and applications, 3rd edn. Academic Press, Burlington, MA

Jackson DI, Cherry NJ (1988) Prediction of a district's graperipening capacity using a Latitude-Temperature Index (LTI) Am J Enol Vitic 39:19-28

Jones GV (2005) Climate change in the western United States grape growing regions. Acta Hortic 41-60

Jones GV (2007) Climate change: observations, projections and general implications for viticulture and wine production. Climate and Viticultural Congress, 10-14 April 2007, Zaragoza. OIV, Paris, p 55-66

Jones GV, Snead N, Nelson P (2004) Geology and wine. VIII. Modeling viticultural landscapes: a GIS analysis of the terroir potential in the Umpqua valley of Oregon. Geosci Can 31:167-178

Jones GV, Moriondo M, Bois BA, Hall A, Duff A (2009) Analysis of the spatial climate structure in viticulture regions worldwide. Bull OIV 82:507-518

Jones GV, Duff AA, Hall A, Myers JW (2010) Spatial analysis of climate in winegrape growing regions in the western United States. Am J Enol Vitic 61:313-326

Keller M (2010) The science of grapevines: anatomy and physiology. Academic Press, Burlington, MA and San Diego, CA 
Magalhães N (2008) Tratado de viticultura: a videira, a vinha e o terroir. Chaves Ferreira Publicações, Lisboa

Magarey R, Seem RC, DeGloria SD (1998) Prediction of vineyard site suitability. Grape Research News 9:1-2. New York State Agricultural Experiment Station, Geneva

Makra L, Vitanyi B, Gal A, Mika J, Matyasovszky I, Hirsch T (2009) Wine quantity and quality variations in relation to climatic factors in the Tokaj (Hungary) winegrowing region. Am J Enol Vitic 60:312-332

Malheiro AC, Santos JA, Fraga H, Pinto JG (2010) Climate change scenarios applied to viticultural zoning in Europe. Clim Res 43:163-177

Malheiro AC, Santos JA, Pinto JG, Jones GV (2012) European viticulture geography in a changing climate. Bull OIV 85:971-973

MATLAB V2014a (2014) MATLAB and Simulink 2014a. MathWorks, Natick, MA

Mills LJ, Ferguson JC, Keller M (2006) Cold-hardiness evaluation of grapevine buds and cane tissues. Am J Enol Vitic 57:194-200

Mitchell KE, Lohmann D, Houser PR, Wood EF and others (2004) The multi-institution North American Land Data Assimilation System (NLDAS): Utilizing multiple GCIP products and partners in a continental distributed hydrological modeling system. J Geophys Res 109:D07S90

Montes C, Perez-Quezada JF, Peña-Neira A, Tonietto J (2012) Climatic potential for viticulture in Central Chile. Aust J Grape Wine Res 18:20-28

Mullins MG, Bouquet A, Williams LE (1992) Biology of the grapevine. Cambridge University Press, Cambridge

Prescott JA (1965) The climatology of the vine (Vitis vinifera L.). The cool limits of cultivation. Trans R Soc S Aust 89: 5-23

Ramos MC, Jones GV, Martínez-Casasnovas JA (2008) Structure and trends in climate parameters affecting winegrape production in northeast Spain. Clim Res 38:1-15

RAWS (Remote Automatic Weather Stations) (2011) RAWS USA climate archive. https://raws.dri.edu (accessed 16 September, 2017)

Rosenberg NJ, Blad BL, Verma SB (1983) Microclimate: the biological environment. Wiley, New York, NY

* Santos JA, Malheiro AC, Pinto JG, Jones GV (2012) Macroclimate and viticultural zoning in Europe: observed trends and atmospheric forcing. Clim Res 51:89-103

Santos JA, Grätsch SD, Karremann MK, Jones GV, Pinto JG (2013) Ensemble projections for wine production in the Douro Valley of Portugal. Clim Change 117:211-225

SAS (2015) SAS software v9.4. SAS Institute, Cary, NC

Takahashi K, Kuranaka M, Miyagawa A, Takeshita O (1976) The effect of wind on grapevine growth; windbreaks for vineyards. Bull Shimane Agric Exp Stn 14:39-83

Tarara JM, Ferguson JC, Hoheisel GA, Perez Peña JE (2005) Asymmetrical canopy architecture due to prevailing wind direction and row orientation creates an imbalance in irradiance at the fruiting zone of grapevines. Agric For Meteorol 135:144-155

Tonietto J, Carbonneau A (2004) A multicriteria climatic

Editorial responsibility: Toshichika Iizumi,

Tsukuba, Japan classification system for grape-growing regions worldwide. Agric Meteorol 124:81-97

*Tóth JP, Végvári Z (2016) Future of winegrape growing regions in Europe. Aust J Grape Wine Res 22:64-72

TTB (Alcohol and Tobacco Tax and Trade Bureau) (2015) American Viticultural Area (AVA). US Department of Treasury, Regulations and Rulings Division. www.ttb. gov/wine/ava.shtml (accessed 6 March, 2015)

UI GSM (2015) The University of Idaho's Gridded Surface Meteorological Data. http://metdata.northwestknowledge. net/. (accessed 20 February, 2015)

USDA-NASS (USDA National Agricultural Statistics Service) (2015) http://quickstats.nass.usda.gov

USHCN (2011) United States Historical Climate Network. http://cdiac.ornl.gov/ftp/ushcn daily/ (last accessed on February 22, 2016)

*Van Leeuwen C, Seguin G (2006) The concept of terroir in viticulture. J Wine Res 17:1-10

Van Leeuwen C, Friant $\mathrm{P}$, Choné X, Trégoat $\mathrm{O}$, Koundouras S, Dubourdieu D (2004) The influence of climate, soil and cultivar on terroir. Am J Enol Vitic 55:207-217

Wample RL, Hartley S, Mills L (2001) Dynamics of grapevine cold hardiness. In: Rantz JM (ed) Proc Am Soc Enol Vitic 50th Anniversary Annual Meeting, June 19-23, 2000, Seattle, WA. ASEV, Davis, CA, p 81-93

White RE (2015) Understanding vineyard soils. Oxford University Press, New York

Williams LE, Dokoozlian NK, Wample R (1994) Grape. In: Schaffer B, Andersen PC (eds) Handbook of environmental physiology of fruit crops, Vol 1. Temperate crops. CRC Press, Boca Raton, FL, p 85-133

Winkler AJ, Cook JA, Kliewer WM, Lider LA (1974) General viticulture, 4th edn. University of California Press, Berkeley

Wolfe W (1999) Site selection in eastern Washington: optimizing sSite and variety choices. In: Watson J (ed) Growing grapes in eastern Washington. Proceedings from the 1998 Washington State University shortcourse for establishing a vineyard and producing grapes. Good Fruit Grower, Yakima, WA, p 27-30

Wolfe W (2001) Vine and vineyard management following low temperature injury. In: Rantz JM (ed) Proc Am Soc Enol Vitic 50th Anniversary Annual Meeting, June 1923, 2000, Seattle, WA. ASEV, Davis, CA, p 101-110

WorldClim (2009) www.worldclim.org/ (accessed 16 September, 2017)

WSW (Washington State Wines) (2015) www.washingtonwine.org/wine-101/regions/ (accessed 16 September, 2017)

Yau IH (2011) Developing a grape site selection GIS for the Inland Pacific Northwest. MSc thesis, Washington State University, Department of Crop and Soil Sciences. Available at www.dissertations.wsu.edu/Thesis/Fall2011/i_yau _092211.pdf

*Yau IH, Davenport JR, Rupp RA (2013) Characterizing inland Pacific Northwest American Viticultural Areas with geospatial data. PLOS ONE 8:e61994

Submitted: January 29, 2018; Accepted: August 14, 2018 Proofs received from author(s): October 10, 2018 